\title{
Hercynian late-post-tectonic granitic rocks from the Fornos de Algodres area (Northern Central Portugal)
}

\author{
M.R. Azevedo ${ }^{\mathrm{a}, *}$, J. Nolan ${ }^{\mathrm{b}}$ \\ a Departamento de Geociências, Universidade de Aveiro, 3800 Aveiro, Portugal \\ ${ }^{\mathrm{b}}$ Department of Geology, Imperial College, Prince Consort Road, London SW7 2BP, UK \\ Received 12 August 1997; accepted 29 June 1998
}

\begin{abstract}
The Fornos de Algodres Complex (FAC) comprises several intrusions of late-post-tectonic Hercynian granitic rocks ranging in composition from hornblende granodiorites and quartz monzodiorites, through coarse porphyritic biotite granites and two-mica granites (coarse-, medium- and fine-grained), to muscovite-rich leucogranites. Field and regional constraints show that the emplacement of this large, composite, batholithic complex post-dates the main Variscan regional deformation phases $\left(D_{1}+D_{2}+D_{3}\right)$ and associated metamorphic events. Field, petrographic and geochemical data suggest a strong genetic relationship between most of the members of the FAC. However, their $\mathrm{Rb}-\mathrm{Sr}$ and $\mathrm{Sm}-\mathrm{Nd}$ isotopic signatures appear to rule out any genetic process involving a single homogeneous source and/or closed-system fractional crystallization of the same parental magma. A model involving hybridization of mantle-derived basaltic liquids with crustal anatectic melts followed by further contamination and fractional crystallization is proposed to explain the isotopic and geochemical variation trends defined by the FAC granitic rocks. (C) 1998 Elsevier Science B.V. All rights reserved.
\end{abstract}

Keywords: Iberian Variscan Fold Belt; Granites; Hybridization; Magma mixing; Fractional crystallization; Assimilation

\section{Introduction}

The Iberian Variscan Fold Belt is a well-exposed cross-section of continental crust affected by Variscan continent-continent collision during Late Devonian to Carboniferous times (Ribeiro et al., 1983; Matte, 1986). It is the southwestern extension of the European Hercynides and constitutes one of the largest domains of the Variscan orogen that has escaped significant reworking by Alpine tectono-metamor-

\footnotetext{
* Corresponding author. Fax: +351-34-370-605; E-mail: mrosario@geo.ua.pt
}

phic events. According to Ribeiro et al. (1990) and Quesada (1991), the evolution of the Iberian Variscan Fold Belt can be described in terms of Late Palaeozoic accretion of a number of exotic terranes to the Iberian Authochthon (Fig. 1), through a long and complex process involving subduction and eventual obduction, followed by oblique collision of a promontory (the corner of the Cantabrian Arc) with the northern continent.

Regional structural constraints show that the majority of the granitic rocks from the Northern Iberian Hercynian massif post-date syn-collisional deformation and thrust nappe emplacement $\left(\mathrm{D}_{1}+\mathrm{D}_{2}\right)$. Granite genesis appears therefore to have occurred only 


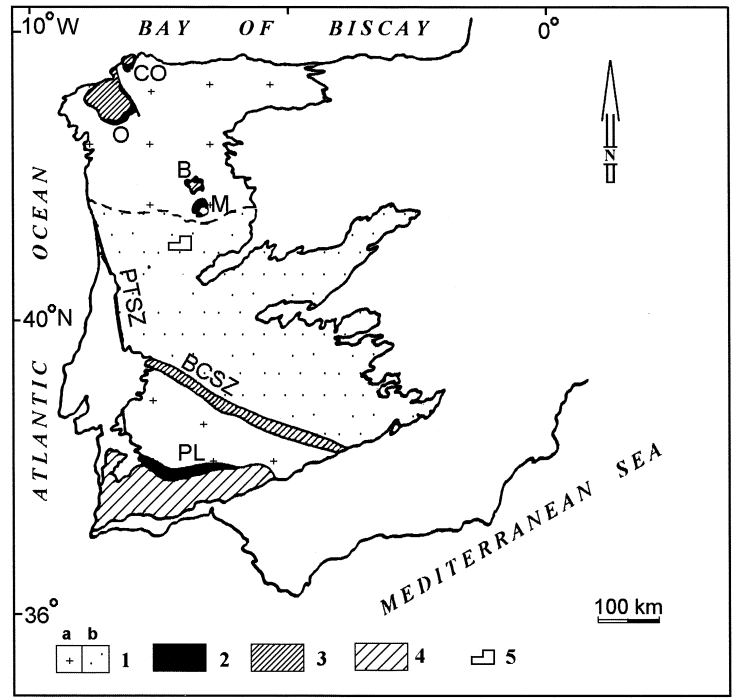

Fig. 1. Palaeozoic tectonostratigraphic terranes in the Iberian Massif (from Ribeiro et al., 1990): 1-Iberian terrane, a-imbricated margins, b-autochthonous/parautochthonous core; 2-Oceanic terranes; 3-Continental 'suspect' terranes of northwest Iberia; 4-South Portuguese terrane; 5-Study area; $\mathrm{CO}-$ Cabo Ortegal; O-Ordenes; $\mathrm{B}$-Bragança; $\mathrm{M}$-Morais complexes; PL_Pulo do Lobo formation; BCSZ_Badajoz-Cordoba Shear Zone; PTSZ_-Porto-Tomar Shear Zone.

very late in the evolution of the Iberian belt and is predominantly correlated with the third Variscan deformation phase $\left(D_{3}\right)$ which is marked by vertical folding and important intra-continental shearing (Noronha et al., 1981; Iglesias and Ribeiro, 1981; Diez Balda et al., 1990). For the reasons mentioned above, the $\mathrm{D}_{3}$ folding phase has been widely used as a time reference marker to classify the Iberian Variscan granitoids into three major groups: (a) prekinematic (380-345 Ma), (b) syn-kinematic (340$320 \mathrm{Ma}$ ) and (c) late- post-kinematic granites (315$270 \mathrm{Ma}$ ) (Capdevila et al., 1973; Ferreira et al., 1987; Pinto et al., 1987).

There is evidence to suggest that granite plutonism was coeval with or post-dated the high- $T$, low- $P$ regional metamorphic episode resulting from thermal relaxation during uplift and erosion (Valle et al., 1993). Such a metamorphic regime is characterized by the attainment of crustal temperatures of 600 to $700^{\circ} \mathrm{C}$ at pressures of 2-4 kbars (Fig. 2), implying up to $14 \mathrm{~km}$ of uplift and erosion subsequent to granite emplacement. A series of deep seismic refraction profiles for the Iberian Peninsula reveal that the Moho is presently located at depths ranging from 23 to $32 \mathrm{~km}$ (Banda et al., 1983; Córdoba et al., 1987; Matias, 1996). As a consequence, it may be presumed that the Northern Iberian Variscan granitic rocks were intruded into a tectonically thickened continental crust at least 33 to $46 \mathrm{~km}$ thick.

It is now accepted by many authors that underplating and emplacement of significant volumes of

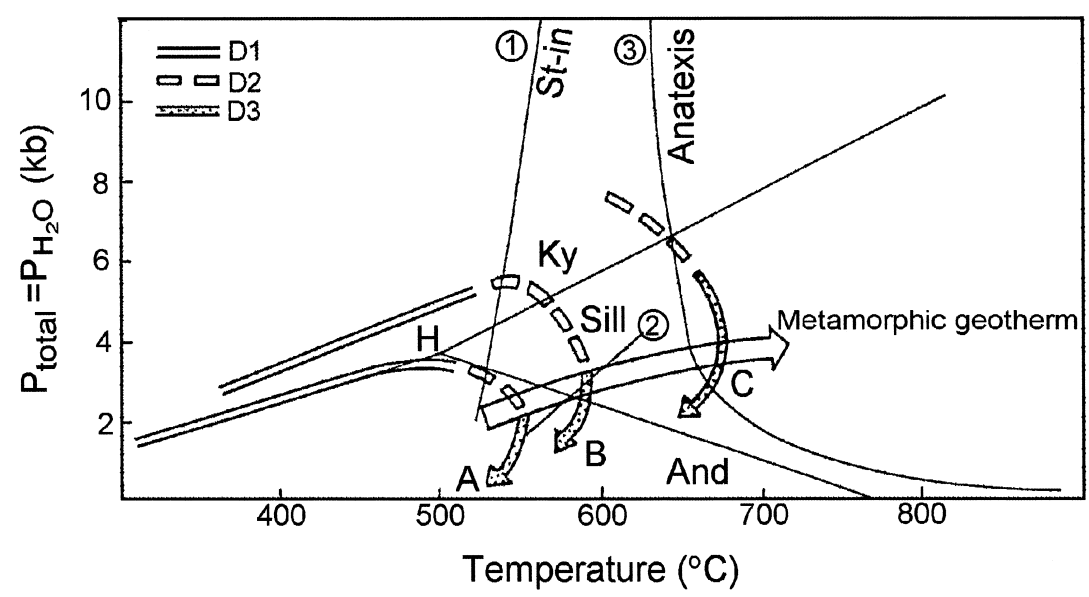

Fig. 2. Metamorphic $P-T$ paths and relation with the major Hercynian deformation phases $\left(D_{1}, D_{2}\right.$ and $\left.D_{3}\right)$ for pelitic sequences of the Porto-Viseu belt (from Valle, 1992): A—staurolite zone; B-sillimanite zone; C-sillimanite + K-feldspar zone; and -andalusite; ky—kyanite; sill—sillimanite; st—staurolite; 1-'staurolite-in' curve (Yardley, 1989); 2-staurolite + muscovite $=$ biotite $+\mathrm{Al}_{2} \mathrm{SiO}_{5}$ (Winkler, 1976); 3-onset of melting (Luth et al., 1964); H-aluminosilicate phase stability field (Holdaway, 1971). 
hot basaltic liquids into the lower crust or at the crust-mantle interface may supply the heat needed to initiate and promote large-scale crustal anatexis in continent-continent collisional tectonic settings during uplift and erosion (e.g., Dewey et al., 1988; England and Houseman, 1988; Bergantz, 1989). However, the nature of the processes responsible for the generation and chemical differentiation of granitic magmas is still controversial. Incremental batch melting, partial melting of distinct source rock materials, fractional crystallization, mixing and/or mingling of magmas with contrasting compositions, crustal contamination and more complex models involving concurrent assimilation and fractional crystallization (AFC) may all play different roles in determining the final characteristics of granitic rocks (e.g., O'Nions et al., 1979; Bernard-Griffiths et al., 1985; Wall et al., 1987; Ortega and Gil Ibarguchi, 1989; Pin and Duthou, 1990; Turpin et al., 1990; Gasquet et al., 1992; Dias and Leterrier, 1994; Beetsma, 1995).

The close spatial and temporal relationship observed between different granite types within the Fornos de Algodres Complex (FAC) therefore provides an opportunity to investigate their petrogenesis allowing some constraints to be placed on the nature of both the sources and mechanisms involved in the formation of granitic rocks in this segment of the Iberian Fold Belt during the Variscan Orogeny.

\section{Geological setting and petrographic characteri- zation}

The Fornos de Algodres area is located well within the Iberian authochthon (Fig. 1). With the exception of a few small bodies of gneisses and deformed syn- $\mathrm{D}_{3}$ granitoids, the majority of the granitic rocks from the FAC occur as discordant, intrusive, late-post-kinematic plutons bearing little or no petrographic evidence of solid state deformation (Fig. 3). The whole batholith was emplaced into metasedimentary rocks of Precambrian-Cambrian to Lower Ordovician age that were strongly affected by both the $\mathrm{D}_{1}$ and $\mathrm{D}_{3}$ deformation phases and late-stage activity related to subvertical shearing and faulting.

Regional metamorphism associated with the main Hercynian deformation events is responsible for the development of prograde metamorphic assemblages that reach sillimanite grade in the metasedimentary sequences of Real, but do not exceed biotite grade in the Matela-Matança formation (Fig. 3). Late thermal metamorphic aureoles were produced in these lithologies by the intrusion of the late-post-kinematic granites. As a result, the Matela-Matança metapelites were extensively transformed into cordieritechiastolite-bearing hornfelses and spotted slates. Finally, all the metamorphic sequences have been subjected to late-stage retrograde metamorphism (sericitization, muscovitization and tourmalinization).

The late-post-kinematic FAC batholith is composed of five major granite units: (1) hornblende granodiorites and quartz-monzodiorites, (2) coarse porphyritic biotite granites, (3) fine and fine-medium grained two-mica granitoids (4) porphyritic and non-porphyritic medium- to coarse-grained two-mica granitoids and (5) muscovite-rich granites (Fig. 3). A detailed petrographic and chemical-mineralogical characterization of these units is given by Azevedo (1996).

The fine to medium grained hornblende granodiorites and quartz monzodiorites (GD) of Trancozelos occur as a small elongate body in the Fornos de Algodres area. Their lobate to cuspate contacts against the coarse porphyritic biotite granites support a coeval emplacement for these two granite units. The GD types are unique in the FAC in having large amounts of mafic minerals. In addition to amphibole (ferro-hornblende) and biotite (Mg-biotite), their main constituents are plagioclase $\left(\mathrm{An}_{28-36}\right)$, quartz and some K-feldspar. Minor phases include titanite, apatite, zircon and opaque minerals (mainly ilmenite). Amphibole geobarometric calculations using the regression lines proposed by Hammarstrom and Zen (1986), Johnson and Rutherford (1989) and Schmidt (1992) yielded a maximum emplacement/crystallization pressure of around $3 \mathrm{kbar}(\sim 10 \mathrm{~km})$ for the Trancozelos granodiorites.

At the presently exposed level, the coarse porphyritic biotite granite (CPBG) is volumetrically the most important lithological type within the FAC, cropping out as a large, irregularly shaped pluton more than $75 \mathrm{~km}$ long and $35 \mathrm{~km}$ large that extends well beyond the limits of the area of this study. A magmatic flow foliation defined by the planar parallelism of the tabular K-feldspar megacrysts is often 


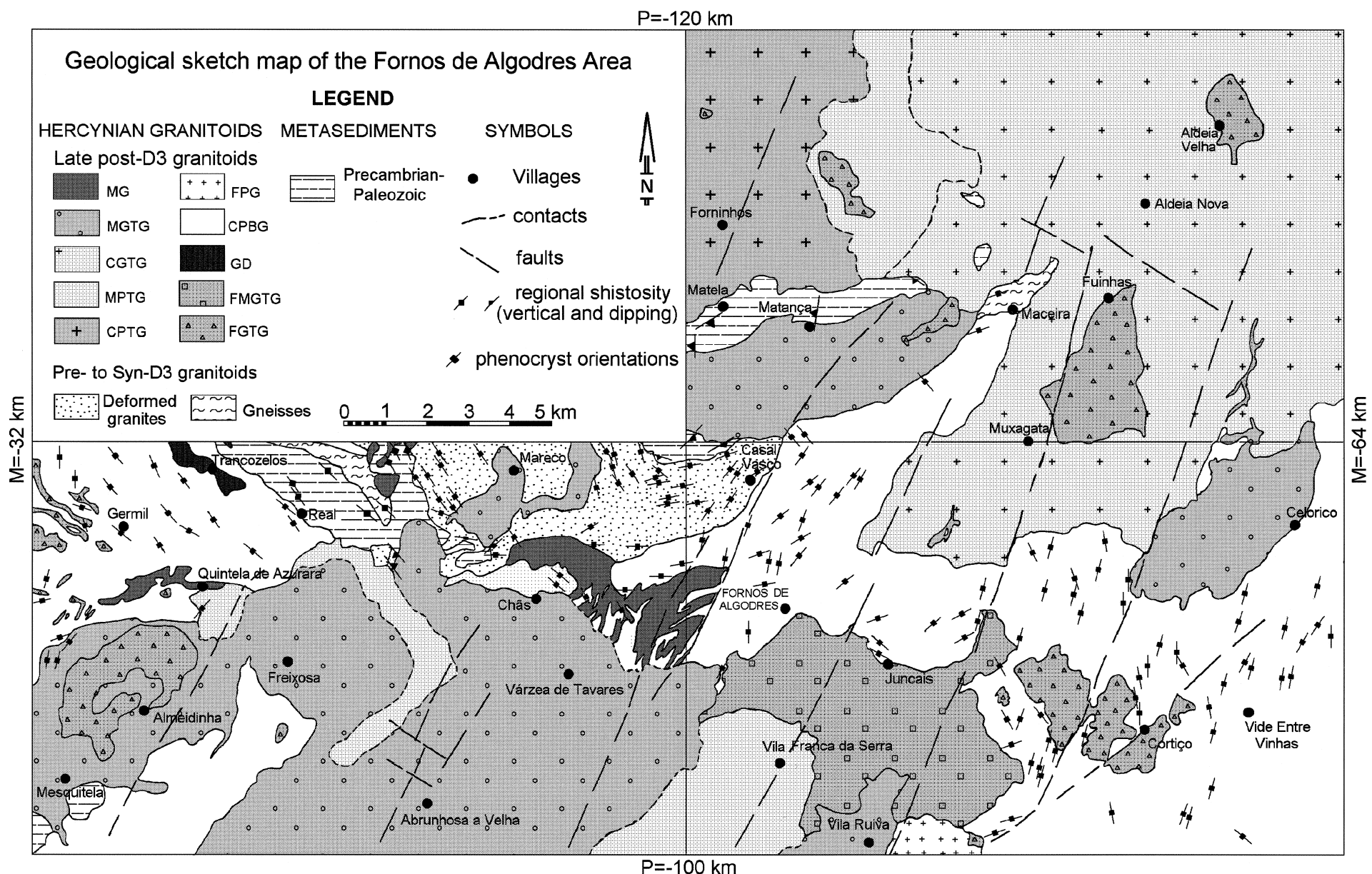

Fig. 3. Geological sketch map of the Fornos de Algodres area. 
visible in this facies although the proportion of oriented megacrysts varies considerably both within and between outcrops (Fig. 3). Mesocratic, fine grained, igneous-textured enclaves (MME) are unevenly distributed throughout the pluton. Their abundance increases towards the contacts between the GD and CPBG types where dense swarms of globular, mafic enclaves are seen to occur within the coarse porphyritic biotite granite. The occurrence of a relatively large interaction zone ( $2 \mathrm{~km}$ wide) between the GD and CPBG facies resulting in the production of hybrid granodioritic rocks provides evidence for the involvement of mixing and mingling processes in their petrogenesis (e.g., Reid et al., 1983; Vernon, 1983, 1984, 1990; Frost and Mahood, 1987; Barbarin and Didier, 1991; Wiebe, 1991). Mineralogically, the CPBG consist of large $\mathrm{K}$-feldspar crystals up to $8 \mathrm{~cm}$ in length, set in a medium- to coarse-grained groundmass of plagioclase $\left(\mathrm{An}_{15-32}\right)$, quartz, K-feldspar (mostly perthitic microcline) and biotite. Accessory minerals are apatite, monazite, zircon, ilmenite and rare xenotime.

The CPBG pluton is crosscut by smaller, circular or polygonal bodies of two-mica granitoids with grain size and textures ranging from fine- and finemedium grained (FGTG and FMGTG), through medium- and coarse-grained (MGTG and CGTG) to
K-feldspar porphyritic (CPTG and MPTG). Their major rock-forming minerals are plagioclase $\left(\mathrm{An}_{5-29}\right)$, K-feldspar (mostly perthitic microcline), quartz, biotite (high-Al biotite) and muscovite. Masses of fibrolite needles and a few andalusite grains were found in some samples of the finer grained varieties (FGTG and FMGTG). Apatite, monazite, zircon, ilmenite and xenotime (rare) are common accessory phases.

The muscovite-bearing granites (MG) form two small intrusions in the SW of the Fornos de Algodres area (Quintela and Bom Sucesso) and several minor occurrences in the NE (Fig. 3). They are fine- to medium-grained equigranular rocks having plagioclase (almost pure albite), quartz, K-feldspar (nonperthitic microcline) and muscovite as their main constituents. Biotite, tourmaline and Mn-rich garnet ( $>10 \%$ spessartine content) are the dominant accessory minerals. Field relationships show that the MG magmas have invaded and permeated the CPBG at a relatively late stage of their crystallization history. Straight-sided, shallowly dipping MG sheets, 1 to 2 $\mathrm{m}$ thick, are seen to crosscut and contain angular fragments of the early intruded coarse porphyritic biotite granites.

Much of the internal variation observed within the FAC batholith can be accounted for by a multiple

\section{Emplacement Sequence}

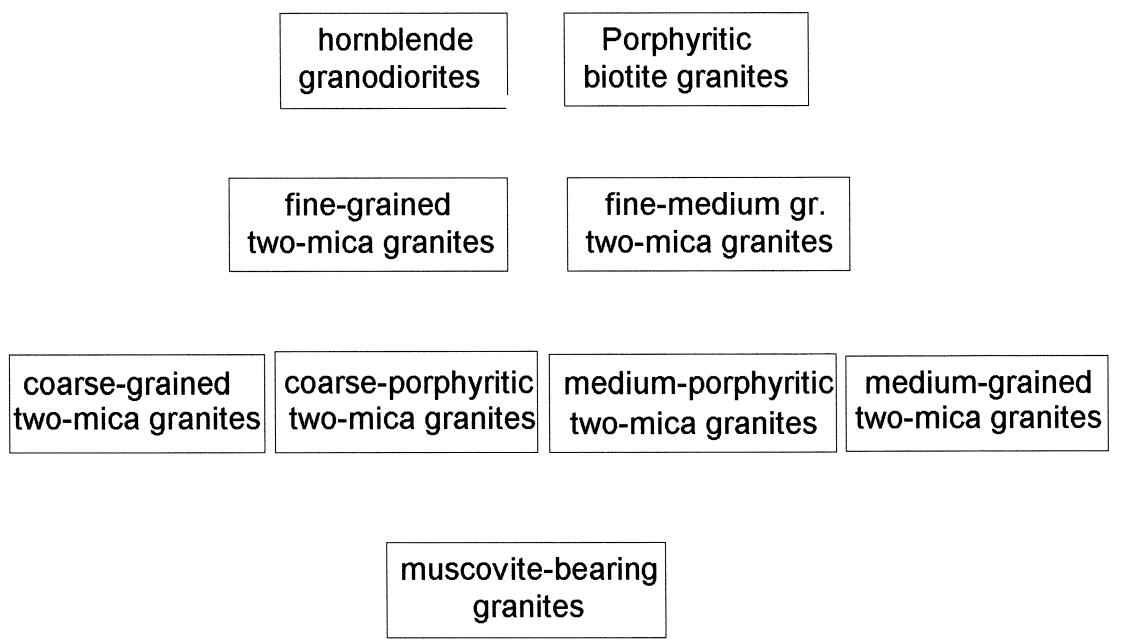

Fig. 4. Schematic diagram showing the proposed emplacement sequence for the late-post-kinematic FAC granitoids. 
Table 1

Major, trace and REE element compositions of the FAC granitoids

\begin{tabular}{|c|c|c|c|c|c|c|c|c|c|c|c|c|c|c|c|c|c|c|c|c|c|c|}
\hline \multirow[t]{2}{*}{ Sample } & \multicolumn{3}{|l|}{ GD } & \multicolumn{2}{|c|}{ Hyb. CPGB } & \multicolumn{4}{|l|}{ CPBG } & \multicolumn{3}{|l|}{ CGTG } & \multicolumn{4}{|l|}{ MGTG } & \multicolumn{2}{|l|}{ MG } & \multicolumn{2}{|l|}{ FGTG } & \multicolumn{2}{|c|}{ FMGTG } \\
\hline & 55 & $190-2$ & $190-3$ & $190-8$ & $190-13$ & 11 & 178 & 182 & 196 & 87 & 114 & 199 & 17 & 45 & 130 & 183 & 9 & 172 & 12 & 145 & 92 & 162 \\
\hline $\mathrm{O}_{2}$ & 60.12 & 0.84 & 60.07 & 61.47 & 65.08 & 70.35 & 71.39 & 71.36 & 71.94 & 72.99 & 75.59 & 73.47 & 73.58 & 71.81 & 72.97 & 72.50 & 75.84 & 75.19 & 72.96 & 74.31 & 73.15 & 2.24 \\
\hline $\mathrm{iO}_{2}$ & 1.19 & 1.33 & 1.00 & 1.16 & 0.77 & 0.75 & 0.36 & 0.41 & 0.39 & 0.17 & 0.24 & 0.13 & 0.16 & 0.26 & 0.22 & 0.20 & 0.07 & 0.05 & 0.28 & 0.23 & 0.21 & 0.37 \\
\hline $\mathrm{l}_{2} \mathrm{O}_{3}$ & 16.25 & 15.85 & 17.08 & 15.98 & 15.69 & 13.45 & 14.29 & 14.70 & 13.93 & 14.18 & 13.50 & 14.69 & 14.40 & 14.87 & 14.09 & 14.44 & 14.10 & 14.33 & 14.07 & 14.08 & 13.81 & 14.49 \\
\hline $\mathrm{e}_{2} \mathrm{O}_{3} \mathrm{t}$ & 6.80 & 6.79 & 6.42 & 6.87 & 4.99 & 4.75 & 2.27 & 2.69 & 2.54 & 1.51 & 1.87 & 1.10 & 1.53 & 2.03 & 1.83 & 1.56 & 0.80 & 0.65 & 2.06 & 1.58 & 1.57 & 2.34 \\
\hline $\mathrm{MnO}$ & 0.10 & 0.12 & 0.09 & 0.11 & 0.07 & 0.07 & 0.04 & 0.04 & 0.04 & 0.04 & 0.03 & 0.02 & 0.03 & 0.03 & 0.04 & 0.03 & 0.04 & 0.04 & 0.04 & 0.02 & 0.03 & 0.04 \\
\hline $\mathrm{gOO}$ & 83 & .28 & 2.08 & & 2.21 & & 0. & & & & 0. & 0.27 & & 0.36 & & & & & & 0.32 & & \\
\hline $\mathrm{aO}$ & 4.84 & 4.57 & 5.32 & & 3.54 & & 1.2 & & & & 0.93 & 0.62 & & 1.07 & 78 & 73 & & & & 0.69 & & 0.95 \\
\hline $\mathrm{Na}_{2} \mathrm{O}$ & 3.69 & 3.87 & 3.98 & & 3.77 & 3.23 & 3.35 & 3.32 & 3.43 & & 3.12 & 3.54 & & 3.31 & 3.29 & 3.49 & 3.72 & 4.16 & & 2.87 & & 2.87 \\
\hline $\mathrm{K}_{2} \mathrm{O}$ & 3.13 & 3.29 & 2.98 & 3.7 & 2.66 & 3.2 & 4.78 & 5.30 & 4.63 & 4.82 & 4.71 & 5.70 & 5.38 & 5.64 & 5.02 & 5.07 & 4. & 4.01 & 4. & 5.24 & & 5.12 \\
\hline${ }_{2} \mathrm{O}_{5}$ & 0 & 0.34 & 0.27 & 0.3 & 0.35 & & 0.24 & 0.22 & & & 0.21 & 0.18 & 0. & & 0.24 & 23 & 18 & 0.15 & 98 & 0.25 & .15 & 0.29 \\
\hline OI & & & 0.72 & & 0.68 & & 0.56 & 0.4 & & & 0.69 & & & & & & & & & & & 84 \\
\hline otal & 99.78 & 99.80 & 100.01 & 100.13 & 99.81 & 100.14 & 99.07 & 100.70 & 99.51 & 99.27 & 101.34 & 100.37 & 100.25 & 100.03 & 99.57 & 99.30 & 100.56 & 100.14 & 100.04 & 100.46 & 99.43 & \\
\hline $\mathrm{Fe}_{2} \mathrm{O}_{3}$ & 1.19 & nd & nd & nd & nd & 0.50 & 0.14 & 0.33 & 0.31 & 0.23 & 0.44 & 0.21 & 0.31 & 0.34 & 0.29 & 0.26 & 0.41 & 0.33 & 0.14 & 0.28 & 0.30 & 0.19 \\
\hline $\mathrm{eO}$ & 5.05 & nd & nd & nd & nd & 3.82 & 1.92 & 2.36 & 2.23 & & 1.29 & 0.80 & 1.10 & 1.52 & 1.39 & 1.30 & 0.35 & 0.29 & 1.73 & 1.17 & 1.14 & 1.93 \\
\hline $\mathrm{Ba}$ & 700 & 530 & 495 & 725 & 670 & 285 & 365 & 640 & 310 & 200 & 275 & 260 & 155 & 440 & 275 & 215 & 75 & 35 & 795 & 365 & 410 & 415 \\
\hline $\mathrm{b}$ & 160 & 165 & & 169 & 184 & 232 & 304 & 270 & 269 & 386 & 319 & 378 & 450 & 378 & 342 & 366 & 412 & 461 & 22 & 299 & 293 & 330 \\
\hline$r$ & 285 & 250 & & & 500 & 11 & 85 & 12 & 95 & 50 & 65 & 5 & 50 & 95 & 60 & 60 & & & & 90 & 75 & \\
\hline $\mathrm{Zr}$ & 260 & 285 & 250 & 310 & 290 & 230 & 160 & 180 & 140 & 70 & 120 & 7 & 90 & 150 & 110 & 90 & 20 & 30 & 190 & 110 & 120 & 170 \\
\hline & & 45 & 30 & 35 & 30 & & 21.7 & 25.9 & 35.1 & 21.1 & 27.3 & & 14.2 & 19.7 & 27.0 & & 10.7 & 6.8 & 23.6 & 15.0 & 29.7 & 16.9 \\
\hline $\mathrm{c}$ & 16.1 & 18 & 1 & 1 & 10 & & 3.6 & 4.9 & 5.5 & 3.6 & 3.3 & & 2.1 & 3.4 & 3.9 & 1.8 & 2.1 & 0.8 & 3.8 & 2.6 & 2.7 & 3.1 \\
\hline$V$ & 100 & 160 & 170 & 100 & 80 & 80 & 20 & 30 & 30 & - & 10 & & - & - & & & - & - & 20 & - & 10 & 20 \\
\hline & 60 & 35 & $<15$ & $<15$ & 55 & 20 & 10 & 2 & 1 & - & 10 & 1 & 10 & - & 20 & 10 & - & - & 0 & 10 & 10 & 20 \\
\hline Ji & 41 & $<15$ & $<15$ & 15 & $<15$ & - & 1 & & 2 & - & & & - & - & 5 & 20 & 10 & - & 0 & & & - \\
\hline $\mathrm{a}$ & & nd & nd & $\mathrm{n}$ & nd & 52.11 & 30. & & & 17.2 & & & 20.8 & & & & & & & & 38.56 & 44.35 \\
\hline $\mathrm{Ce}$ & 77.3 & nd & nd & nd & nd & 112.95 & 66.03 & 71.83 & 73.55 & 38.74 & nd & & 46.27 & 83.73 & & 49.90 & 10 & 58 & 108 & 69.88 & 82.86 & 100.39 \\
\hline & & nd & & & & & & & & & nd & & & & & & & & & & 9.42 & 12.01 \\
\hline$d$ & 34.8 & nd & & & & & 29. & & & & & & 18 & & & & & & & 28.99 & 33.58 & 44.35 \\
\hline $\mathrm{Sm}$ & .17 & nd & nd & nd & nd & 10.54 & 6.33 & 6.85 & 7.14 & 4.25 & nd & & & 6.89 & 6.46 & 5.36 & & 0.93 & 7.12 & 6.64 & 7.14 & . $\quad 9.07$ \\
\hline $\mathrm{Eu}$ & & nd & nd & nd & nd & & 0.7 & & & & nd & & 0. & 0.6 & 0.40 & 0.36 & 0. & 0. & 0. & 0.5 & 0.60 & 0.62 \\
\hline Jd & & nd & nd & nd & nd & & & & & & nd & & & & & & & & & 4. & & 5.71 \\
\hline Dy & 5.18 & nd & nd & nd & nd & & 4.3 & 5.08 & 5.8 & 3.75 & nd & & 3.2 & 4.11 & & & 1.7 & & & 3.30 & 4.97 & 3.44 \\
\hline Но & 0.98 & nd & nd & nd & nd & & 0.79 & 0.98 & & 0.67 & nd & & & 0.73 & 0.87 & & & & 0.93 & 0.54 & 0.96 & 0.61 \\
\hline & 2.76 & nd & nd & nd & nd & & 2.3 & 2.8 & 3.4 & 1.77 & nd & & 1.1 & 1.92 & 2.34 & 1.83 & 0.99 & 0. & 2.68 & 1.41 & 2.91 & 1.58 \\
\hline $\mathrm{Yb}$ & 2.45 & nd & nd & nd & nd & & 2.1 & 2.71 & 3.81 & 1.59 & nd & & 0.8 & 1.67 & 2.11 & & 1.02 & & 2.50 & 1.32 & 2.98 & 1.42 \\
\hline $\mathrm{Lu}$ & 0.36 & nd & nd & nd & nd & 0.64 & 0.31 & 0.38 & 0.55 & 0.21 & nd & 0.18 & 0.12 & 0.24 & 0.27 & 0.23 & 0.19 & 0.16 & 0.36 & 0.18 & 0.43 & 0.21 \\
\hline
\end{tabular}

-: Below detection limit.

nd: Not determined. 
emplacement mechanism involving periodic injection of successively more evolved magma batches (Fig. 4). It should be stressed, however, that the local development of gradational transitions and intermingling structures at the contacts between time-separated granite bodies suggests that the entire FAC granite sequence could have been emplaced within a relatively short range of time with partial overlap between consecutive intrusive phases.

\section{Analytical methods}

Over one hundred and fifty representative samples of the various FAC granite units have been analysed for major and some trace elements $(\mathrm{Ba}, \mathrm{Cr}, \mathrm{Ni}, \mathrm{Sr}$, $\mathrm{V}, \mathrm{Zr}$ ) by inductively coupled plasma atomic emis- sion (ICP-AES) at the University of London Imperial College (IC). Ferrous iron was determined by titration and $\mathrm{Rb}$ was analysed by flame emission spectrometry (FES). Subsets of these samples have been analysed for REE, Y, Sc and $\mathrm{Hf}$ at the University of London Royal Holloway and Bedford New College (RHBNC) using cation exchange separation and ICP-AES (Watkins and Nolan, 1990, 1992). Analytical errors are less than $5 \%$ for most elements. Electron microprobe analysis were performed at IC on a JEOL 733 superprobe equipped with a Link Energy Dispersive System at $15 \mathrm{kV}$ for $100 \mathrm{~s}$ counting-time and a ZAF 4 correction program.

Isotopic analysis were performed on a VG 354 multicollector thermal ionization mass spectrometer at RHBNC. $\mathrm{Rb}$ and $\mathrm{Sr}$ were determined by XRF and $\mathrm{Sm}$ and $\mathrm{Nd}$ by ID using the chemical separation

Table 2

$\mathrm{Sr}$ isotopic data for the FAC granites

\begin{tabular}{|c|c|c|c|c|c|c|}
\hline Samples & $\mathrm{Rb}$ & $\mathrm{Sr}$ & ${ }^{87} \mathrm{Rb} /{ }^{86} \mathrm{Sr}$ & ${ }^{87} \mathrm{Sr} /{ }^{86} \mathrm{Sr}$ & ${ }^{87} \mathrm{Sr} /{ }^{86} \mathrm{Sr}_{i}$ & $\varepsilon \mathrm{Sr}_{i}$ \\
\hline CPBG-11 & 213.1 & 120.2 & 5.1220 & $0.729356 \pm 17$ & 0.70749 & 47.40 \\
\hline CPBG-37 & 230.4 & 151.5 & 4.3918 & $0.72492 \pm 2$ & 0.70617 & 28.67 \\
\hline CPBG-39 & 262.8 & 126.0 & 6.0278 & $0.73302 \pm 2$ & 0.70729 & 44.51 \\
\hline CPBG-80 & 270.9 & 122.3 & 6.4036 & $0.735956 \pm 12$ & 0.70862 & 63.43 \\
\hline CPBG-103 & 251.3 & 119.9 & 6.0577 & $0.733502 \pm 15$ & 0.70764 & 49.55 \\
\hline CPBG-169 & 210.9 & 151.6 & 4.0173 & $0.72454 \pm 2$ & 0.70739 & 45.98 \\
\hline CPBG-178 & 308.3 & 76.9 & 11.6154 & $0.758282 \pm 11$ & 0.70870 & 64.52 \\
\hline CPBG-182 & 281.9 & 120.1 & 6.7860 & $0.736431 \pm 31$ & 0.70746 & 46.99 \\
\hline CPBG-190 & 337.6 & 99.6 & 9.8135 & $0.751097 \pm 16$ & 0.70920 & 71.72 \\
\hline CPBG-196 & 260.8 & 90.1 & 8.3755 & $0.745046 \pm 26$ & 0.70929 & 72.97 \\
\hline CPBG-215 & 262.0 & 105.0 & 7.2150 & $0.73787 \pm 2$ & 0.70707 & 41.42 \\
\hline Hyb-190-8 & 171.6 & 278.9 & 1.782 & $0.712913 \pm 64$ & 0.70530 & 16.38 \\
\hline Hyb-190-13 & 181.0 & 538.0 & 0.974 & $0.709371 \pm 56$ & 0.70521 & 15.07 \\
\hline CGTG-81 & 330.8 & 47.4 & 20.2874 & $0.792710 \pm 25$ & 0.70899 & 68.61 \\
\hline CGTG-86 & 329.8 & 57.4 & 16.6840 & $0.781371 \pm 16$ & 0.71253 & 118.75 \\
\hline CGTG-87 & 389.3 & 44.9 & 25.2504 & $0.81154 \pm 6$ & 0.70734 & 45.18 \\
\hline CGTG-114 & 322.4 & 63.6 & 14.7022 & $0.76918 \pm 2$ & 0.70851 & 61.75 \\
\hline CGTG-118 & 345.3 & 61.5 & 16.2966 & $0.77697 \pm 10$ & 0.70972 & 78.95 \\
\hline CGTG-204 & 329.2 & 79.1 & 12.0566 & $0.75721 \pm 2$ & 0.70746 & 46.80 \\
\hline CGTG-222 & 364.7 & 56.7 & 18.6877 & $0.78713 \pm 2$ & 0.71001 & 83.11 \\
\hline CGTG-223 & 332.9 & 59.5 & 16.2396 & $0.777080 \pm 18$ & 0.71007 & 83.85 \\
\hline MGTG-17 & 452.0 & $46.78 \pm 1$ & 28.182 & $0.82733 \pm 6$ & 0.71104 & 97.62 \\
\hline MGTG-67 & 388.6 & $54.509 \pm 1$ & 20.725 & $0.79460 \pm 7$ & 0.70908 & 69.81 \\
\hline MGTG-69 & 533.2 & $50.68 \pm 1$ & 30.710 & $0.83662 \pm 5$ & 0.70989 & 81.41 \\
\hline MGTG-183 & 372.4 & $51.464 \pm 3$ & 21.044 & $0.79738 \pm 2$ & 0.71054 & 90.59 \\
\hline MGTG-184 & 365.3 & $51.38 \pm 5$ & 20.701 & $0.79592 \pm 11$ & 0.71050 & 89.96 \\
\hline MGTG-186 & 373.7 & $44.22 \pm 2$ & 24.614 & $0.81142 \pm 10$ & 0.70985 & 80.77 \\
\hline MGTG-187 & 372.4 & $42.16 \pm 2$ & 25.730 & $0.81509 \pm 9$ & 0.70891 & 67.49 \\
\hline GD-190-2 & 184.4 & 286.1 & 1.866 & $0.713157 \pm 64$ & 0.70519 & 14.75 \\
\hline GD-190-3 & 140.4 & 304.0 & 1.337 & $0.71080 \pm 11$ & 0.70509 & 13.35 \\
\hline
\end{tabular}


Table 3

$\mathrm{Nd}$ isotopic data for the FAC granites

\begin{tabular}{lllllll}
\hline Samples & $\mathrm{Nd}$ & $\mathrm{Sm}$ & ${ }^{147} \mathrm{Sm} /{ }^{144} \mathrm{Nd}$ & ${ }^{143} \mathrm{Nd} /{ }^{144} \mathrm{Nd}$ & ${ }^{143} \mathrm{Nd} /^{144} \mathrm{Nd}_{i}$ & $\varepsilon \mathrm{Nd}{ }_{i}$ \\
\hline CPBG-37 & 33.33 & 6.93 & 0.1257 & $0.512396 \pm 6$ & 0.512149 & -2.01 \\
CPBG-103 & 37.07 & 8.02 & 0.1308 & $0.512399 \pm 40$ & 0.512142 & -2.14 \\
CPBG-178 & 29.39 & 6.03 & 0.1240 & $0.512313 \pm 7$ & 0.512069 & -2.03 \\
CPBG-215 & 30.27 & 6.24 & 0.1247 & $0.512393 \pm 8$ & 0.512148 & -4.15 \\
CGTG-81 & 14.32 & 3.40 & 0.1437 & $0.512325 \pm 14$ & 0.512052 & -3.63 \\
MGTG-187 & 14.85 & 3.53 & 0.1437 & $0.512352 \pm 9$ & 0.512079 & 0.512252 \\
GD-190-3 & 33.30 & 6.90 & 0.1255 & $0.512499 \pm 21$ & 0.512281 & 0.512275 \\
GAB-41A & 15.00 & 3.17 & 0.1275 & $0.512531 \pm 7$ & 0.56 \\
GAB-41BD & 14.00 & 3.11 & 0.1303 & & & +0.45 \\
\hline
\end{tabular}

${ }^{87} \mathrm{Sr} /{ }^{86} \mathrm{Sr}_{i}$ and $\varepsilon \mathrm{Nd}_{i}$ calculated at $300 \mathrm{Ma}$ (Viseu Gabbros, GD and CPBG) and at $290 \mathrm{Ma}$ (two-mica granitoids), using ${ }^{143} \mathrm{Nd} /{ }^{144} \mathrm{Nd}=$ 0.512638 and ${ }^{147} \mathrm{Sm} /{ }^{144} \mathrm{Nd}=0.1967$ as CHUR parameters (Faure, 1986).

technique described by Shaw (1991). The ${ }^{87} \mathrm{Sr} /{ }^{86} \mathrm{Sr}$ and ${ }^{143} \mathrm{Nd} /{ }^{144} \mathrm{Nd}$ ratios were normalized to 0.1194 and 0.7219, respectively (Thirlwall, 1991). Reproducibility of SRM 987 standard was $0.710247 \pm 2$ (2 $\sigma$ of 33 analyses). $\mathrm{Rb}-\mathrm{Sr}$ isochron calculations were performed using a computer program developed by J.C. Roddick and modified by M.F. Thirlwall, after York (1969). Additional $\mathrm{Sr}$ and $\mathrm{Nd}$ isotopic analyses were obtained on the VG 354 multicollector thermal ionization mass spectrometer at the Centro de Pesquizas Geocronológicas of the University of São Paulo (Brazil).

Major-, trace- and rare-earth element data for selected samples of the different FAC granite units are presented in Table 1 . The $\mathrm{Rb}-\mathrm{Sr}$ and $\mathrm{Sm}-\mathrm{Nd}$ isotopic results are listed in Tables 2 and 3.

\section{Major and trace element geochemistry}

Selected major- and trace-element variation diagrams for the full spectrum of rock types found in the FAC are illustrated in Fig. 5. The total iron content (wt.\% $\mathrm{Fe}_{2} \mathrm{O}_{3} \mathrm{t}$ ) was used as a differentiation index in preference to the more conventional Harker type plots because it allows a better discrimination between the different FAC granite units. Compared to $\mathrm{SiO}_{2}\left(58.75-75.80\right.$ wt.\%), $\mathrm{Fe}_{2} \mathrm{O}_{3} \mathrm{t}$ displays a much wider range of variation ( 7.80 to $0.57 \mathrm{wt} . \%$ ) and decreases with increasing degree of magmatic evolution.

In the $\mathrm{Fe}_{2} \mathrm{O}_{3}$ t-oxide plots shown in Fig. 5a-d, the entire FAC granitoid sequence defines a single, co- herent trend for most major elements, characterized by a regular decrease of $\mathrm{CaO}, \mathrm{MgO}$ and $\mathrm{TiO}_{2}$ contents from the least evolved hornblende granodiorites to the highly fractionated muscovite-rich granites. Despite some scatter, the mafic microgranular enclaves and the hybrid facies of the porphyritic biotite granites tend to fill the compositional gap between the GD and CPBG varieties.

There are, however, persistent differences in trace element behaviour within the group of the two-mica granites. For similar ranges of $\mathrm{Fe}_{2} \mathrm{O}_{3} \mathrm{t}$ values, the finer grained varieties (FGTG and FMGTG) exhibit significantly higher $\mathrm{Ba}, \mathrm{Sr}, \mathrm{Zr}$ contents, lower $\mathrm{Rb}$ abundances and steeper variation trends than the coarser two-mica granites (Fig. 5e-h). Their REE chondrite normalized patterns are also slightly more fractionated $\left[(\mathrm{La} / \mathrm{Yb})_{\mathrm{N}}=8-21\right]$ than those of any of the other granite types (Fig. 6a). In contrast, the GD, CPBG, CGTG and MGTG facies show a striking uniformity in the shape of their REE patterns with well developed $\mathrm{Eu}$ negative anomalies $(\mathrm{Eu} / \mathrm{Eu} *=$ 0.19-0.67), moderate to high LREE/HREE ratios $\left[(\mathrm{La} / \mathrm{Yb})_{\mathrm{N}}=6-19\right]$, little LREE fractionation $\left[(\mathrm{Ce} / \mathrm{Sm})_{\mathrm{N}}=2-4\right]$ and considerable overlap between individual units (Fig. 6b). This has led to the subdivision of the FAC granitic rocks into two distinct, genetically unrelated, suites: (a) the 'main' suite comprising the hornblende granodiorites, the coarse porphyritic biotite monzogranites, the coarseto medium-grained porphyritic and non-porphyritic two-mica granites and the muscovite-rich granites and (b) a subordinate suite represented by the FGTG and FMGTG. 

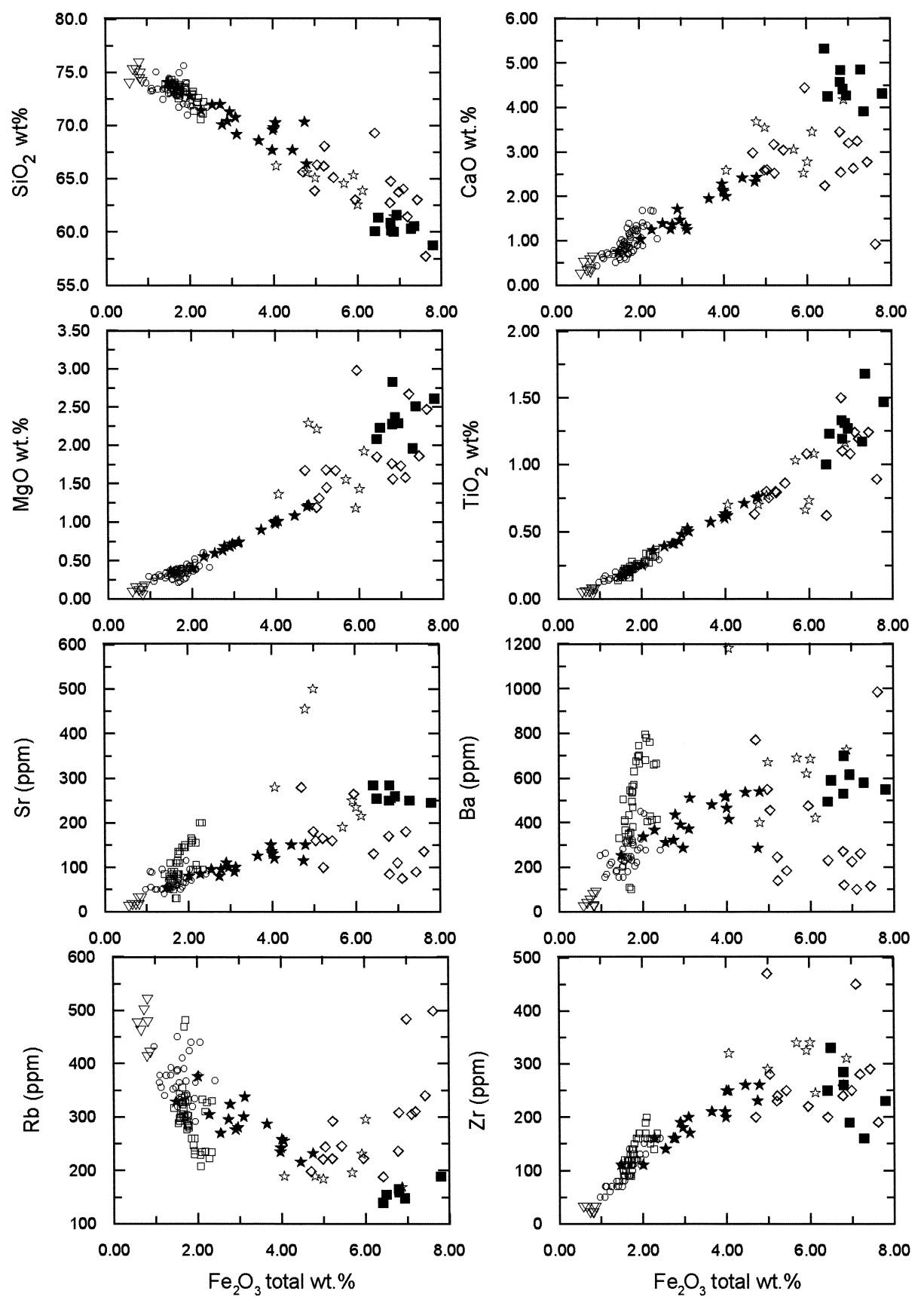

$\begin{array}{ll}\text { GD } & \text { is } \text { CPBG Hybrids } \\ \star \text { CPBG } & \diamond \mathrm{MME}\end{array}$

MPTG, CGTG, MGTG $\nabla$ MG FMGTG and FGTG

Fig. 5. Selected major- and trace-element variation diagrams for the FAC granitoids. 

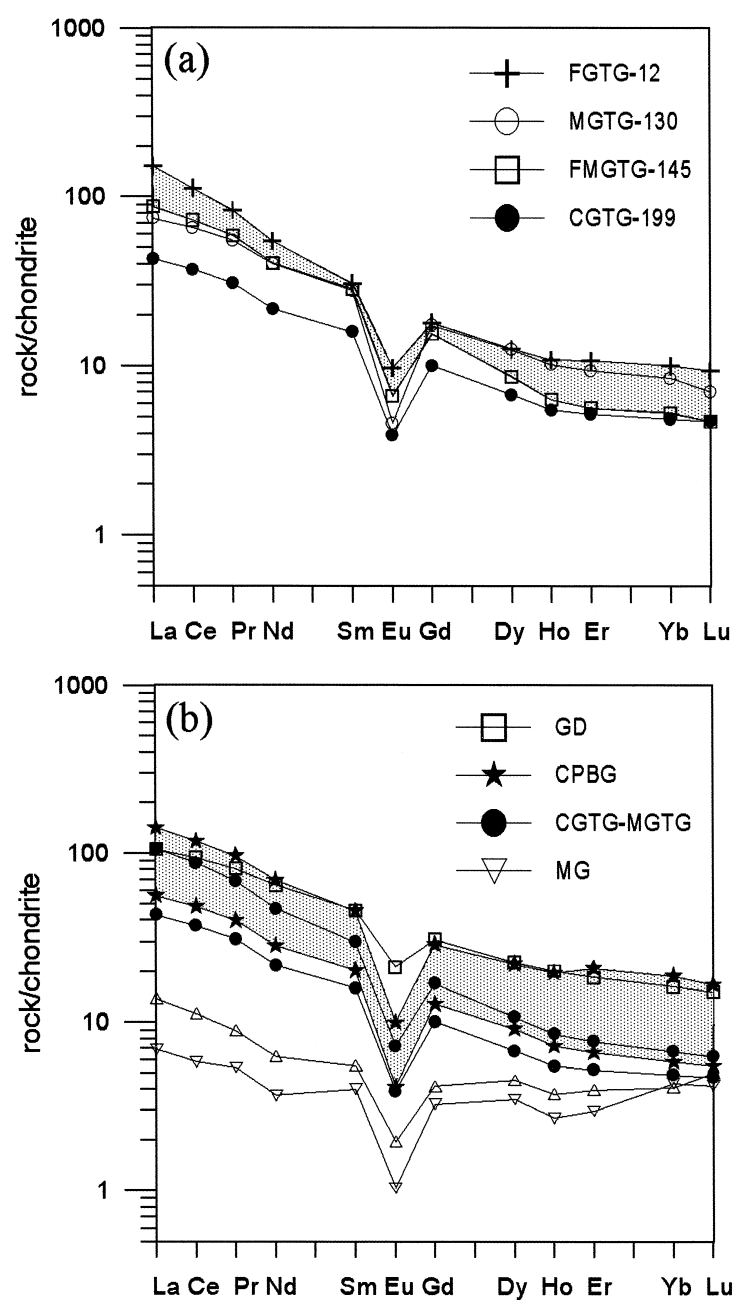

Fig. 6. REE chondrite normalized patterns for the FAC granitoids. Normalization constants from Evensen et al. (1978). The samples are keyed in order of decreasing $\mathrm{Fe}_{2} \mathrm{O}_{3} \mathrm{t}$ contents in diagram (a). Shadowed areas represent the range of REE chondrite normalized values for the FGTG-FMGTG (a) and the CPBG (b).

As referred to above, the widespread occurrence of mafic microgranular enclaves (MME) within the $\mathrm{CPBG}$ and the presence of complex hybrid zones at the contacts between the hornblende granodiorites and the CPBG appear to support the operation of mixing and/or mingling mechanisms between mafic and acid magmas in the petrogenesis of the more primitive members of the main FAC suite. However, many of the MME are Ba- and Sr-depleted and $\mathrm{Rb}$-enriched relative to their host granitoids and no consistent variation pattern can be inferred for the whole MME population in the diagrams of Fig. 5. Similar cases have been reported by Bussy (1991) and Orsini et al. (1991), who attributed the compositional diversity in MME to contrasts in the type and extent of chemical and mechanical interaction affecting each batch of basic magma. In particular, bi-directional chemical transfer induced either by volatile migration or diffusion may explain the anomalous behaviour shown by a number of MME and CPBG hybrid rocks in major- and trace-element plots.

Despite the field evidence in favour of the involvement of magma mixing in the genesis of the main granite series, the lack of linear inter-element relationships in some plots (Fig. $5 \mathrm{e}-\mathrm{h}$ ) suggests that this was not the only mechanism responsible for the production of the FAC granite melts. Much of the chemical and petrographic variation of the suite can be accounted for by fractionation of a mineral assemblage containing plagioclase, amphibole, titanite and ilmenite from a GD parental magma, followed by plagioclase (increasingly more sodic), biotite, $\mathrm{K}$ feldspar and quartz crystallization at later stages of magmatic evolution. Major- and trace-element numerical models support this assumption (Azevedo, 1996). In such a fractional crystallization model, it is possible to ascribe both the observed $\mathrm{Eu}$ negative anomalies and the $\mathrm{Ca}$ and $\mathrm{Sr}$ compatible behaviour to the early separation of plagioclase, whilst amphibole, biotite and ilmenite extraction would have produced the progressive depletion of $\mathrm{Mg}$ and $\mathrm{Ti}$ in the successively formed residual liquids. Because the REE (other than $\mathrm{Eu}$ ) are not partitioned into the modally important mineral phases of the FAC granitoids, the continuous depletion observed within the CPBG, CGTG, MGTG and MG types was probably controlled by the removal of monazite (LREE) and zircon plus xenotime (HREE). The results of REE mass balance modelling for selected samples of the FAC granites (Azevedo, 1996) demonstrate that the accessory minerals have an importance far outweighing their modal proportions in controlling the whole-rock REE distribution pattern displayed by the CPBG, CGTG and MGTG. Monazite incorporates most of the LREE whereas apatite, zircon and xenotime (when present) account for more than $65 \%$ of the total HREE and Y contents. Fractionation of only very small amounts of these mineral phases may 
therefore have been responsible for the systematic REE depletion within the main suite granites.

The presence of curvilinear variation trends on trace element plots (e.g., $\mathrm{Ba}-, \mathrm{Rb}-, \mathrm{Zr}-\mathrm{Fe}_{2} \mathrm{O}_{3} \mathrm{t}$ ) is consistent with the fractional crystallization model and may be interpreted in terms of sequential changes in both the nature and amount of the mineral fractionating assemblage. The increase in the rate of Ba-depletion and Rb-enrichment at $\approx 4.0$ wt. $\%$ $\mathrm{Fe}_{2} \mathrm{O}_{3} \mathrm{t}$ could therefore have resulted from a major change in the mineral fractionating assemblage ( $\mathrm{Pl}+$ $\mathrm{Hbl} \pm \mathrm{Bt}$ to $\mathrm{Pl}+\mathrm{Bt}+\mathrm{Kfs}+\mathrm{Qtz})$ while the inflections on the $\mathrm{Zr}$ and LREE trends (at \pm 6.0 and 3.0 wt. $\% \mathrm{Fe}_{2} \mathrm{O}_{3} \mathrm{t}$ contents, respectively) would, on the other hand, reflect the onset of significant zircon and monazite crystallization.

The compositional evolution of biotites in suites of granitic rocks has important petrogenetic implications and provides a way of classifying their host rocks (Czamanske et al., 1981; Nachit et al., 1985). Using the $\mathrm{Al}_{\text {total }}-\mathrm{Mg}$ diagram of Nachit et al. (1985), the biotites from the GD samples plot within the subalkaline field, those of the CPBG and MME extend from the subalkaline- through the calc-alkaline to the alumino-potassic fields and the biotites of the two-mica granites fall well within the alumino-potassic domain (Fig. 7). Taken together, the biotite data define a continuous trend of systematic $\mathrm{Al}$ enrichment and comparatively less $\mathrm{Mg}$ depletion with increasing whole-rock differentiation. According to Nachit et al. (1985) and Dias and Leterrier

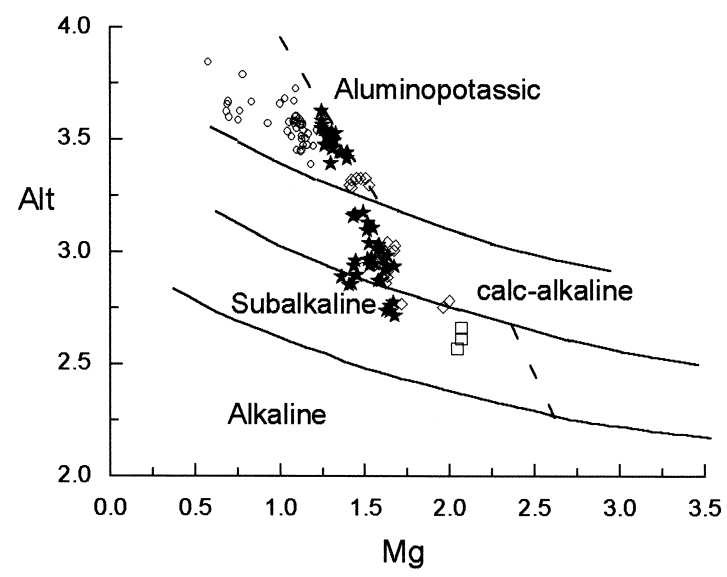

Fig. 7. Al total Mg diagram (Nachit et al., 1985) for biotites of the FAC granitoids. Symbols as stated in Fig. 5.
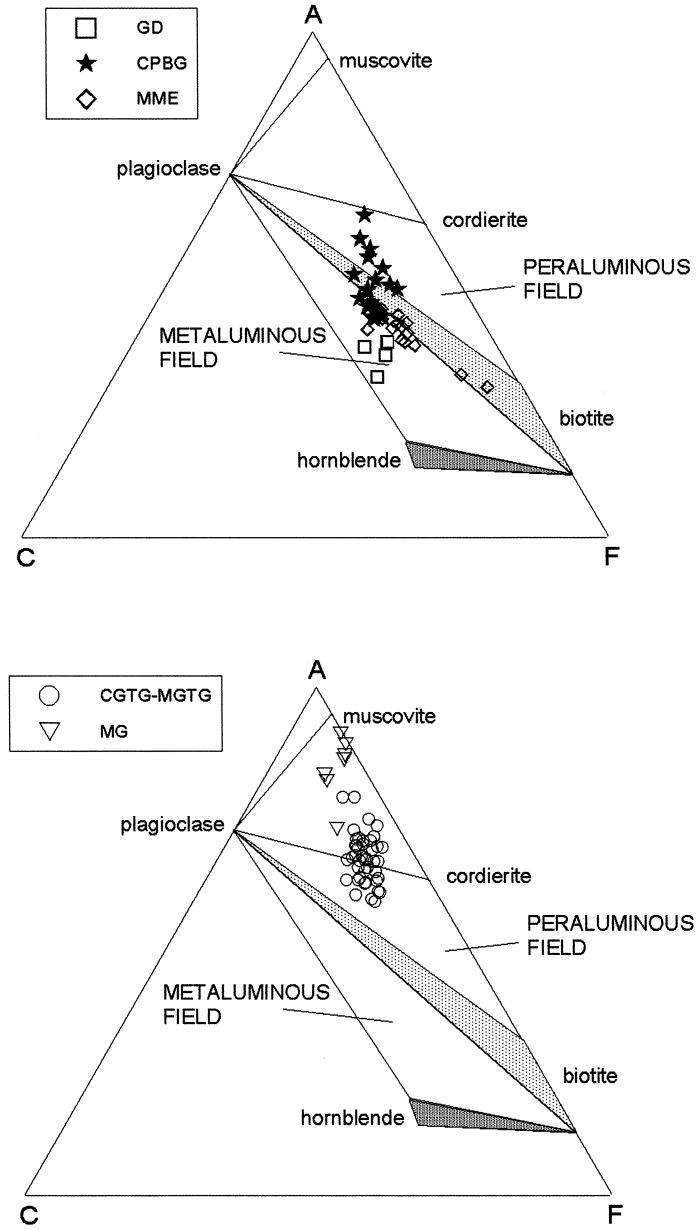

Fig. 8. ACF (atomic proportions of $\mathrm{Al}-\mathrm{Na}-\mathrm{Ca}$ ) diagrams for the FAC granitoids. Fields from White (1990).

(1994), trends with such a steep slope are not easily reconciled with an origin by simple closed-system fractionation because the $\mathrm{Al}$ and $\mathrm{Mg}$ parameters are expected to evolve simultaneously and produce smoother evolutionary trends in the $\mathrm{Al}_{\text {total }}-\mathrm{Mg}$ diagram. Although the biotite compositional variation within the different members of the FAC could reflect the evolution of genetic unrelated parental magmas, the observed trends suggest that combined magma mixing and fractional crystallization (MFC) and/or AFC processes may also have played a dominant role in the generation of the main suite granites.

Inspection of the ACF diagram (Fig. 8) reveals that the hornblende granodiorites are the only facies 
of the FAC batholith with a distinctive I-type signature. They have low A/CNK ratios (0.87-0.95), normative corundum $<1 \%$. and fall within the field of the metaluminous granites containing amphibole and biotite in the ACF plot, implying source rock materials of mafic to intermediate igneous composition or an infracrustal derivation (Chappell, 1984; Chappell and Stephens, 1988; White and Chappell, 1988). In contrast, the CPBG samples lie either within the domain of the granitoids with biotite as the only ferromagnesian mineral or just above the plagioclase-biotite tie line. At first sight, their slightly peraluminous character $(\mathrm{A} / \mathrm{CNK}=1.00$ $1.15)$ points to an S-type provenance. However, the majority of the CPBG samples have $\mathrm{A} / \mathrm{CNK}$ ratios below the S-type threshold of 1.1 and relatively low ${ }^{87} \mathrm{Sr} /{ }^{86} \mathrm{Sr}$ initial ratios $(<0.708)$ indicating that these granites may not have been exclusively derived from supracrustal sources. It is now generally accepted that some I-type magmas become moderately peraluminous for high degrees of fractionation and/or assimilation of large volumes of metasedimentary material (e.g., Brown et al., 1984; White et al., 1986; Atherton and Sanderson, 1987; White, 1990). Given the lack of compositional discontinuity between the GD and CPBG types and their close spatial and temporal relationship, it is highly likely that the latter corresponds to modified I-type granitoids.

As expected from their chemical and mineralogical characteristics, the samples of the coarser grained two-mica units (MPTG, CGTG and MGTG) and muscovite-bearing varieties (MG) plot entirely within the peraluminous field and should therefore be classified as S-type granitoids. Nevertheless, there are reasons to believe that the MPTG, CGTG, MGTG and MG magmas were not generated solely from partial melting of pure metasedimentary protoliths. Their relatively low peraluminous mineral content (modal proportions of muscovite generally similar to those of biotite) and ${ }^{87} \mathrm{Sr} /{ }^{86} \mathrm{Sr}$ initial ratios $(<0.709)$ together with the persistent lack of restitic material and the existence of coherent geochemical trends between these units and both the CPBG and GD suggests a cogenetic origin for all the members of the main FAC granite suite. Furthermore, the progressive separation of highly peraluminous mineral phases (or restite) from true S-type melts will tend to cause a systematic decrease in the $\mathrm{A} / \mathrm{CNK}$ ratios whilst, on the other hand, the early crystallization of metaluminous mineral phases from I-type granite magmas is expected to produce the reverse evolutionary trend (Chappell and White, 1974; Wyborn and Chappell, 1986). The A/CNK variation within the 'main' FAC granite series is therefore consistent with an I-type derivation involving a significant contribution of a sedimentary component. This would explain the very high A/CNK values $(>1.15)$ exhibited by the most evolved members of the sequence.

\section{Sr and $\mathrm{Nd}$ isotopic data}

In the $\mathrm{Rb}-\mathrm{Sr}$ isochron diagram (Fig. 9a), the eleven samples of the coarse porphyritic biotite granites define a linear array giving an 'age' of $325 \pm 16$ Ma with an initial ${ }^{87} \mathrm{Sr} /{ }^{86} \mathrm{Sr}$ ratio of $0.7054 \pm 14$ $(M S W D=9.2)$. In view of its high MSWD, the time significance of this errorchron is probably in doubt. Recalculation without samples 37, 80, 196 and 215 lowers the age to $315 \pm 9 \mathrm{Ma}$ and improves the MSWD to a value of 2.2 (Fig. 9b). However, this age may also be fortuitous since there is no obvious geological explanation for the exclusion of the samples mentioned above. The difficulty in dating the CPBG suggests incomplete homogenization of the $\mathrm{Sr}$ isotopic ratios at the time of crystallization and may either reflect isotopic heterogeneity of source materials, contamination of magmas during emplacement or two-component mixing.

For comparison purposes, two samples from a small gabbroic body intimately associated with the CPBG massif in the Viseu region (Beetsma, 1995) and additional $\mathrm{Sr}$ isotopic data for the hornblende granodiorites and the hybrid facies of the CPBG were also plotted in the ${ }^{87} \mathrm{Rb} /{ }^{86} \mathrm{Sr}-{ }^{87} \mathrm{Sr} /{ }^{86} \mathrm{Sr}$ diagram. These samples plot clearly off the CPBG isochron (Fig. 9b) indicating that a closed-system fractional crystallization model cannot explain the evolution of the main FAC granitoid series. The hornblende granodiorites and related CPBG hybrids have, apparently, achieved isotopic equilibrium and define an isochron corresponding to an age of $303 \pm$ $17 \mathrm{Ma}(\mathrm{MSWD}=0.25)$. On the basis of regional constraints and $\mathrm{Rb}-\mathrm{Sr}$ whole-rock geochronological data for other late-post-kinematic coarse porphyritic 
(a)

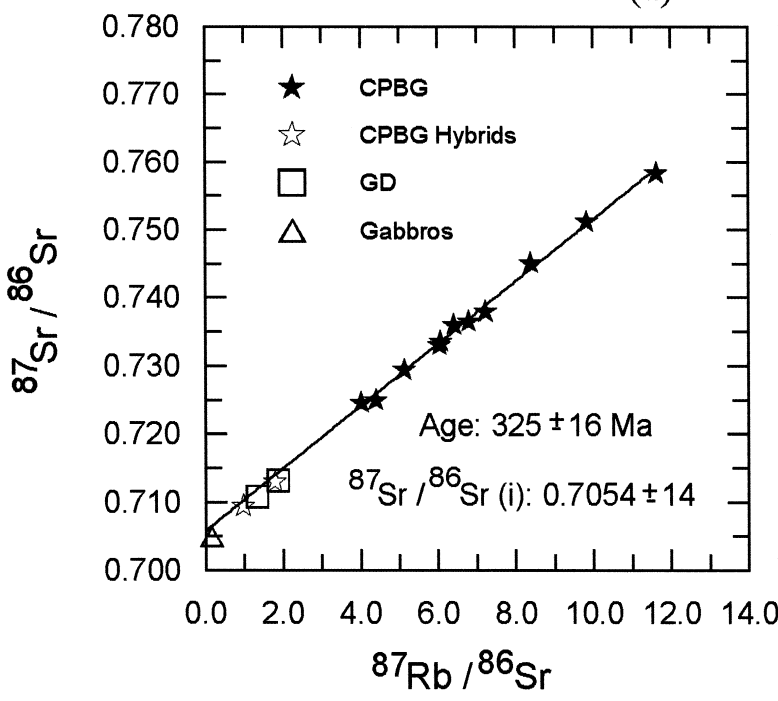

(c)

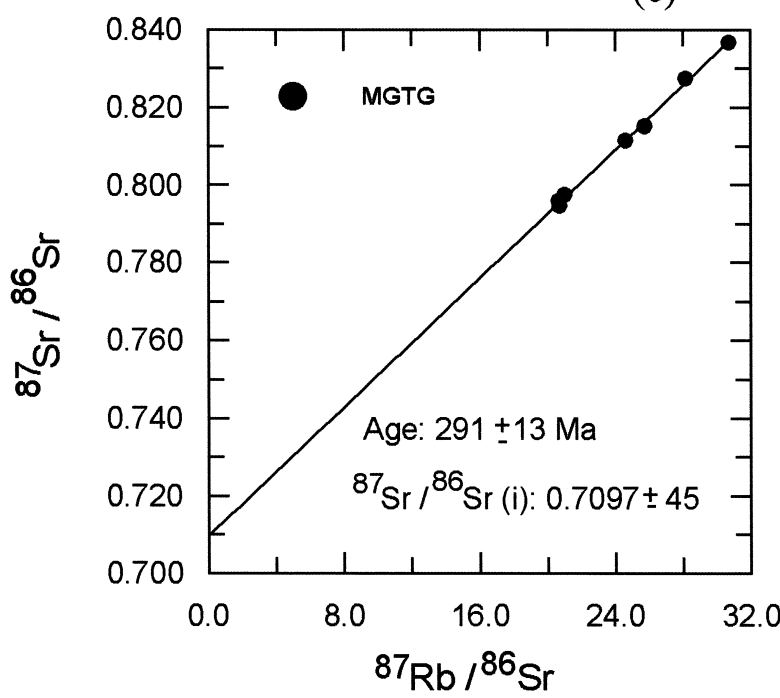

(b)

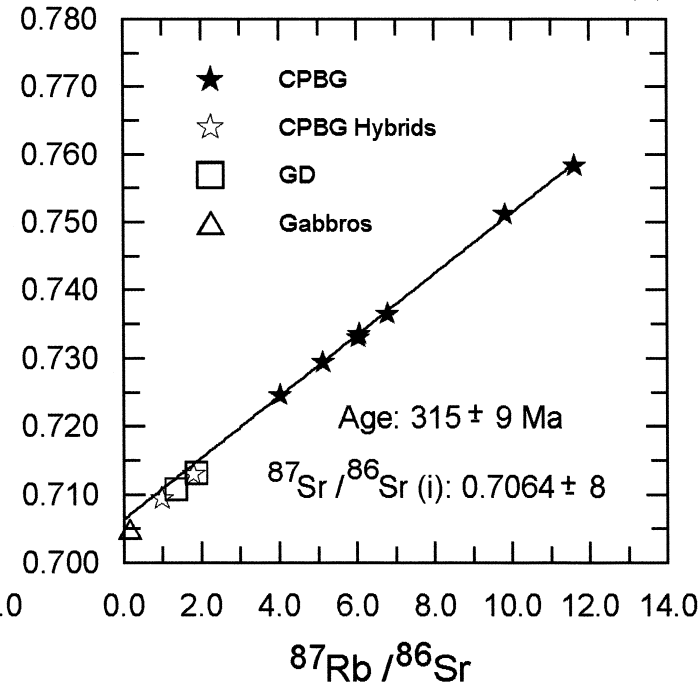

(d)

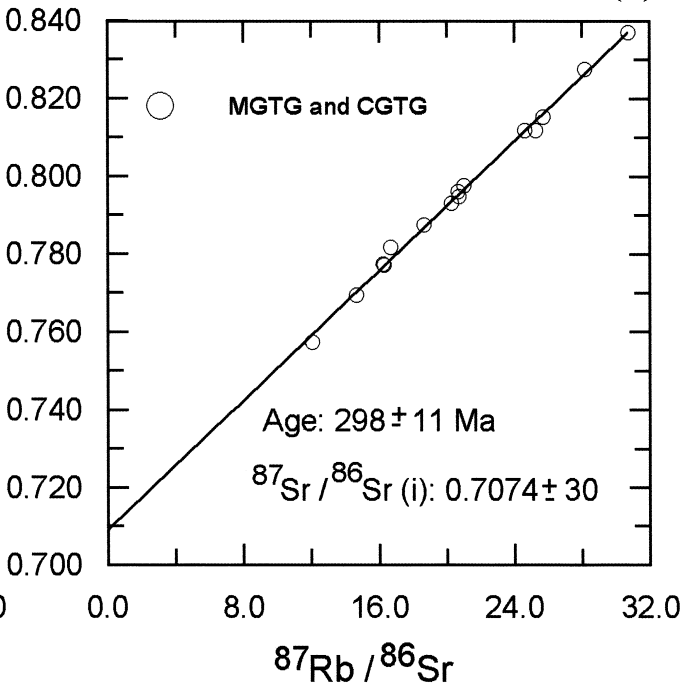

Fig. 9. $\mathrm{Rb}-\mathrm{Sr}$ isochron diagrams for the FAC granitoids.

biotite granites of the same massif (Ferreira et al., 1987; Beetsma, 1995), the presumed age for the CPBG and mafic to intermediate intrusive rocks is 295-280 Ma. The data presented here point to a slightly older age $(\approx 300 \mathrm{Ma})$.

Fig. 9c shows that the seven samples of the MGTG granite are approximately co-linear on a ${ }^{87} \mathrm{Sr} /{ }^{86} \mathrm{Sr}$ vs. ${ }^{87} \mathrm{Rb} /{ }^{86} \mathrm{Sr}$ diagram, yielding a $\mathrm{Rb}-\mathrm{Sr}$ whole-rock isochron of $291 \pm 13 \mathrm{Ma}(\mathrm{MSWD}=4.9)$.
Field relationships indicate that the MGTG and CGTG could have been emplaced roughly at the same time. As such, the eight CGTG samples were plotted on the same $\mathrm{Rb}-\mathrm{Sr}$ isochron diagram (Fig. 9d). Taken together, the 15 samples of two-mica granitoids define an errorchron of $298 \pm 11$ Ma with an initial ${ }^{87} \mathrm{Sr} /{ }^{86} \mathrm{Sr}$ ratio of $0.7074 \pm 30(\mathrm{MSWD}=$ 5.2). Despite the relatively high MSWD, the date obtained is within the maximum and minimum age 
limits of pluton emplacement suggested by geological constraints. According to Ferreira et al. (1987) and Beetsma (1995), the two-mica monzogranites pre-date the coarse porphyritic biotite granites in the intrusion sequence of the late-post- $\mathrm{D}_{3}$ granitoid complexes and have ages of 315-300 Ma. There is, however, evidence to suggest that this is not the case in the Fornos de Algodres area where the CGTG and MGTG are seen to develop sharp intrusive contacts against the CPBG. Although the relatively large age gap $(\approx 10 \mathrm{Ma})$ between the intrusion of the CPBG and the two-mica granites (CGTG and MGTG) would, at first sight, exclude a genetic relationship between these granite bodies, the intrusive relationships displayed by the FAC granites with metasedimentary wall rocks of different metamorphic grade and syntectonic granitoids is compatible with an evolution in long-lived, deep-seated magma chambers and intermittent emplacement of the successive granite plutons at progressively higher crustal levels (Beetsma, 1995). It is therefore possible that the members of the FAC have been emplaced through a relatively long period of time.

The lack of $\mathrm{Sr}$ isotopic homogeneity both within and between the members of the main FAC granite suite rules out an origin by simple fractionation of a common parental magma, but is not incompatible with the involvement of mixing and/or AFC processes in their petrogenesis. As pointed out by DePaolo (1981), this type of mechanisms can affect the isotopic composition of granite plutons and induce significant isotopic heterogeneity. The mixing hypothesis may be assessed by plotting the ${ }^{87} \mathrm{Sr} /{ }^{86} \mathrm{Sr}$ initial ratios of the analysed samples against their $\mathrm{Fe}_{2} \mathrm{O}_{3} \mathrm{t}$ and $\mathrm{Sr}$ contents (Fig. 10a and b, respectively). Data consistent with mixing will tend to lie along hyperbolic curves on ratio-element plots and yield strong linear correlations on ratio-ratio diagrams when the denominators of the two ratios are identical (Langmuir et al., 1978; Faure, 1986). The hyperbolic mixing curve defined by the main suite FAC granitoid samples on the ${ }^{87} \mathrm{Sr} /{ }^{86} \mathrm{Sr}_{i}-\mathrm{Fe}_{2} \mathrm{O}_{3} \mathrm{t}$ and ${ }^{87} \mathrm{Sr} /{ }^{86}$ $\mathrm{Sr}_{i}$-Sr diagrams may therefore be ascribed to mixing of two components with contrasting initial $\mathrm{Sr}$ isotopic ratios.

The $\mathrm{Sr}$ and $\mathrm{Nd}$ initial ratios $\left(\mathrm{Sr}_{i}\right.$ and $\left.\mathrm{Nd}_{i}\right)$ and the $\varepsilon \mathrm{Nd}_{i}-\varepsilon \mathrm{Sr}_{i}$ values for the CPBG, GD and Viseu gabbros were determined using an age of $300 \mathrm{Ma}$
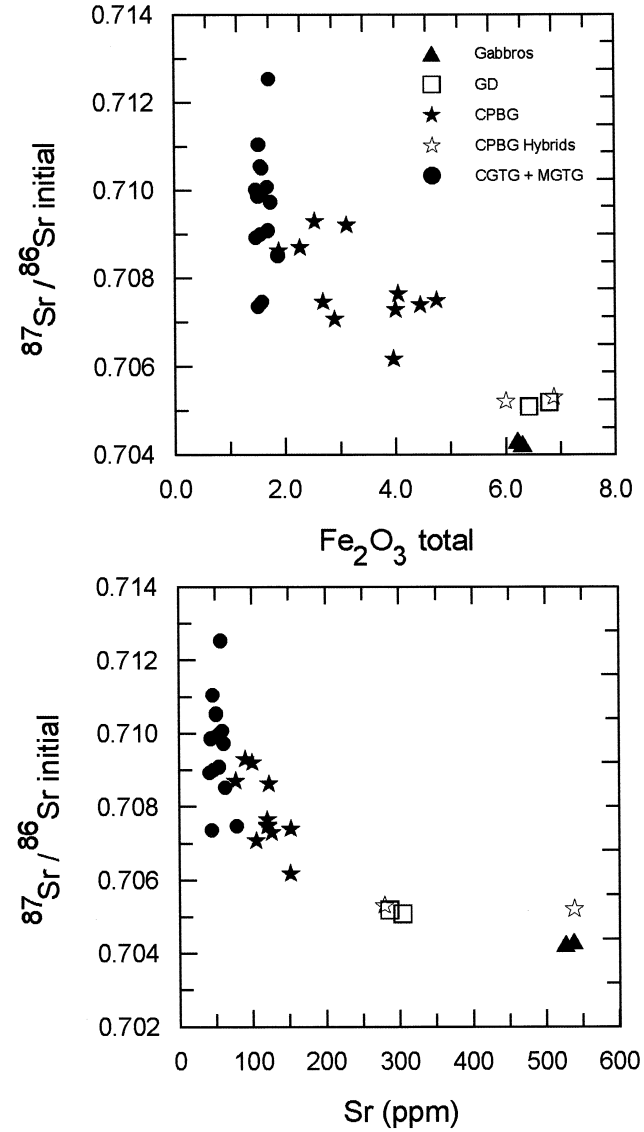

Fig. 10. ${ }^{87} \mathrm{Sr} /{ }^{86} \mathrm{Sr}_{i}-\mathrm{Fe}_{2} \mathrm{O}_{3} \mathrm{t}$ and ${ }^{87} \mathrm{Sr} /{ }^{86} \mathrm{Sr}_{i}$-Sr diagrams for the FAC granitoids.

whereas the MGTG and CGTG isotopic data were recalculated back to $290 \mathrm{Ma}$ (Tables 2 and 3). As expected from their $\mathrm{Sr}$ isotopic behaviour, the different units of the main granitoid suite display a relatively large range of $\mathrm{Nd}_{i}$ and $\varepsilon \mathrm{Nd}_{i}$ values. In spite of the scarcity of $\mathrm{Nd}$ isotopic data, it is possible to subdivide the sequence into several groups according to their $\mathrm{Nd}$ isotopic signatures: (1) the hornblende granodiorites and the Viseu gabbros are the least enriched with initial $\mathrm{Nd}$ compositions varying between 0.51225 and 0.51228 and positive $\varepsilon \mathrm{Nd}_{i}$ values (0.01 and 0.56 , respectively), (2) three of the CPBG samples (37, 103 and 215) show almost identical $\mathrm{Nd}_{i}$ isotopic ratios $(0.51215)$ whilst sample 178 exhibits a considerably lower value (0.51207), (3) the two-mica granite samples are, within error, iso- 


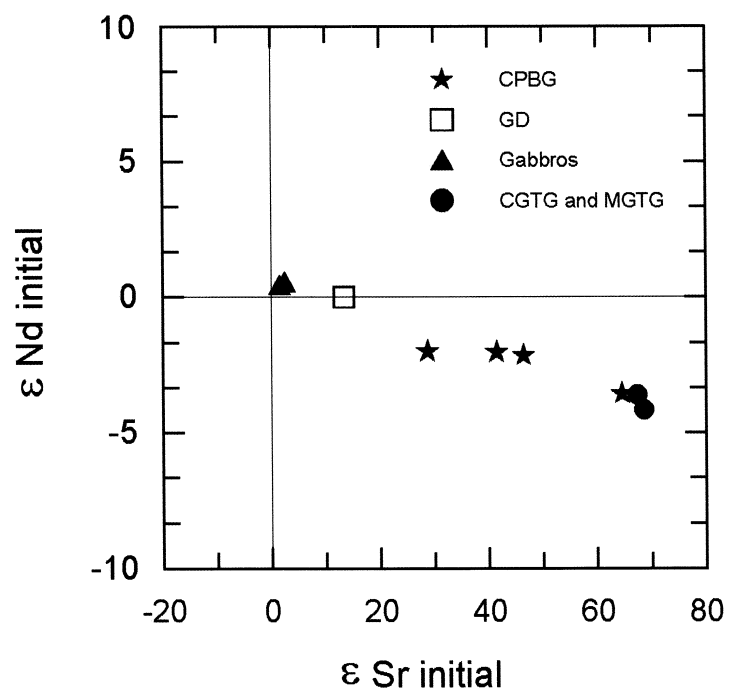

Fig. 11. $\varepsilon \mathrm{Sr}_{i}-\varepsilon \mathrm{Nd}_{i}$ diagram for the FAC granitoids.

topically homogeneous and have the lowest $\mathrm{Nd}_{i}$ ratios $\left({ }^{143} \mathrm{Nd} /{ }^{144} \mathrm{Nd}_{i}=0.51205\right.$ to 0.51208$)$.

The analysed samples define a strong negative correlation in the $\varepsilon \mathrm{Sr}_{i}-\varepsilon \mathrm{Nd}_{i}$ diagram (Fig. 11), corroborating the possibility of a mixed origin for the entire FAC granite sequence. Such a co-variation has been interpreted by many authors in terms of mixing of a high $\mathrm{Rb} / \mathrm{Sr}-$ low $\mathrm{Sm} / \mathrm{Nd}$ with a low $\mathrm{Rb} / \mathrm{Sr}$-high $\mathrm{Sm} / \mathrm{Nd}$ source components (e.g., DePaolo and Wasserburg, 1979; Allègre and Ben Othman, 1980; DePaolo, 1981; Halliday et al., 1981; McCulloch and Chappell, 1982; Liew and McCulloch, 1985; Pickett and Wasserburg, 1989). As discussed below, there is a wide spectrum of source reservoirs capable of yielding the two (or more) mixing end-members: (1) depleted and/or enriched mantle, (2) mafic and/or felsic metaigneous lower crustal materials, (3) lower crustal metasedimentary granulites and (4) middle to upper crustal metasedimentary rocks and/or orthogneisses.

\section{Petrogenesis of the FAC granitoids}

Recent studies on Hercynian and pre-Hercynian rocks from the Iberian Massif (Peucat et al., 1990; Dias and Leterrier, 1994; Beetsma, 1995; Tassinari et al., 1995) allow some constraints to be placed on the petrogenesis of the FAC granitoids. Fig. 12 illustrates the range of initial $\mathrm{Sr}$ and $\mathrm{Nd}$ isotopic compositions for the Iberian Hercynian late-post- $\mathrm{D}_{3}$ granitoids and related basic to intermediate rocks. The fields of $\mathrm{Sr}$ and $\mathrm{Nd}$ isotopic compositions for several possible protoliths (corrected to $320 \mathrm{Ma}$ ) are also plotted in this diagram.

The majority of the late-post- $\mathrm{D}_{3}$ granitoids and associated mafic and intermediate intrusive rocks have initial $\varepsilon \mathrm{Nd}$ values varying between -4.2 to +0.5 . This is not easily accounted for by simple partial melting of the available metasedimentary and/or felsic metaigneous crustal lithologies (Fig. 12). In fact, their initial $\mathrm{Sr}-\mathrm{Nd}$ isotope compositions appear to be best explained by mixing between two discrete source components with discrepant $\mathrm{Sr}-\mathrm{Nd}$ isotopic characteristics. At first sight, any of the crustal units presently exposed in the Central Iberian and Ossa Morena Zones (fields 3, 4, 5 and 7) could have provided the high $\varepsilon \mathrm{Sr}-\mathrm{low} \varepsilon \mathrm{Nd}$ mixing endmember. However, the $\varepsilon \mathrm{Nd}_{320}$ values for the metasedimentary rocks from both the allochthonous complexes and the 'Serie Negra' (fields 3 and 5) are so low that the contribution of this type of material was probably minor.

The precise identity of the mafic end-member (low $\varepsilon \mathrm{Sr}$-high $\varepsilon \mathrm{Nd}$ ) is also problematic. Although the presence of mafic and intermediate rocks with positive $\varepsilon \mathrm{Nd}_{i}$ and low $\varepsilon \mathrm{Sr}_{i}$ values (field 1) might be taken to indicate the involvement of a mantle component in the generation of the late-post- $\mathrm{D}_{3}$ granitoids, it is difficult to find conclusive proof for such a direct input of mantle material. The eventual participation of basic magmas with geochemical signatures similar to the Viseu gabbros as the low $\varepsilon \mathrm{Sr}$-high $\varepsilon \mathrm{Nd}$ mixing end-member is, nevertheless, strongly suggested by the close spatial and temporal relationship between the CPBG and these gabbroic bodies in the Viseu region. As shown by Beetsma (1995), the slightly depleted $\mathrm{Sr}$ and $\mathrm{Nd}$ isotopic signatures of the latter are well explained by contamination of either $\mathrm{N}$ - or E-MORB mafic magmas with small amounts of crustal material $(\sim 10 \%)$.

The samples of the different units of the FAC fall well within the fields defined by the late-post- $\mathrm{D}_{3}$ granitoids and plot along a curvilinear array on the ${ }^{87} \mathrm{Sr} /{ }^{86} \mathrm{Sr}_{i}-{ }^{143} \mathrm{Nd} /{ }^{144} \mathrm{Nd}_{i}$ diagram (Fig. 12). From inspection of this figure, it is apparent that a simple 

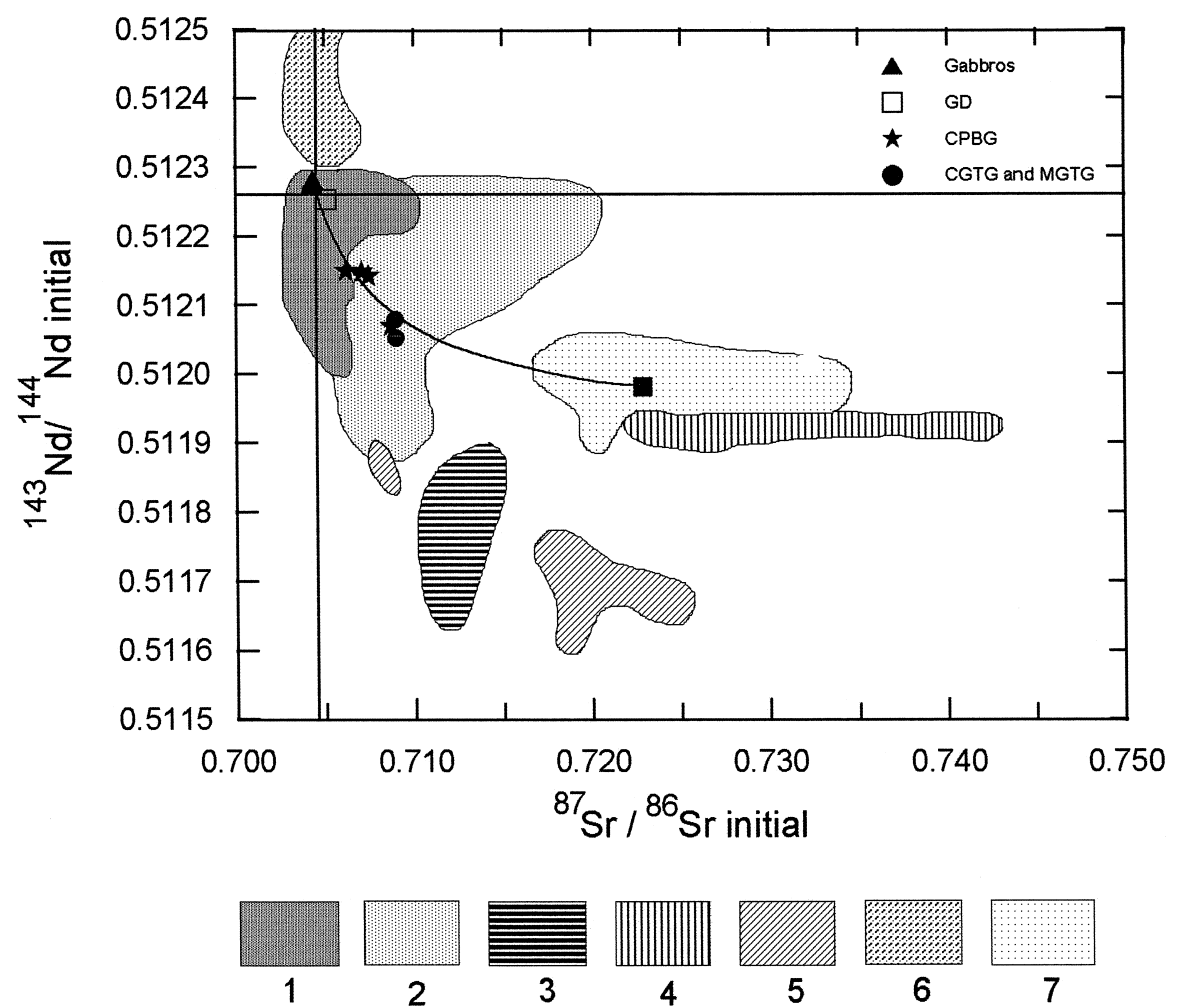

Fig. 12. ${ }^{143} \mathrm{Nd} /{ }^{144} \mathrm{Nd}_{\text {initial }}$ vs. ${ }^{87} \mathrm{Sr} /{ }^{86} \mathrm{Sr}_{\text {initial }}$ variation diagram for the North Portuguese late-post-tectonic granitoids showing the location of the FAC granitoid data and a hypothetical mixing curve between the Viseu gabbros and the Late Proterozoic/Lower Cambrian Iberian metasediments (modified from Beetsma, 1995). Fields (1) and (2) refer to late-post-tectonic mafic and intermediate intrusives and related granitoids, respectively (data from Dias and Leterrier, 1994 and Beetsma, 1995). Source materials include: (3) undifferentiated metasediments from allochthonous complexes (Peucat et al., 1990) (4) orthogneisses from Miranda do Douro and Lagoa (Beetsma, 1995), (5) upper crustal metasediments of Late Proterozoic ('Serie Negra'), Ordovician and Silurian age (Beetsma, 1995), (6) lower crustal basic granulites (Peucat et al., 1990) and (7) upper crustal metasediments from the CXG (Late Proterozoic-Cambrian) (Beetsma, 1995; Tassinari et al., 1995).

binary mixing curve drawn between the Viseu gabbros and Late Proterozoic/Cambrian immature metasedimentary rocks of the CXG (greywackes) recalculated to $300 \mathrm{Ma}$ provides a good fit to the FAC data points. Two alternative scenarios may therefore be proposed: (1) a scenario where the low $\mathrm{Sr}-$ high $\mathrm{Nd}$ mixing end-member corresponds to contaminated basaltic liquids directly extracted from the mantle (N-MORB or E-MORB) and (2) a scenario where the main source reservoir for the mafic component is the basic metaigneous lower crust (field 6). In the first case, the genesis of the main suite parental magmas is expected to be dominated by hybridization and/or AFC mixing processes between mantle- and crustal-derived components, while the latter hypothesis ascribes a fundamental role to mixing of distinct, but entirely crustal source regions. Further contamination and fractional crystallization of the 'mixed' granitoid melts would, in both cases, have generated the entire range of granite types present in the main granite suite.

The two-mica granites have, on average, lower $\varepsilon \mathrm{Sr}_{i}$ and higher $\varepsilon \mathrm{Nd}_{i}$ isotope ratios than those of both the Iberian syn- $\mathrm{D}_{3}$ peraluminous granites $\left(\varepsilon \mathrm{Sr}_{i}\right.$ $=49$ to $150 ; \varepsilon \mathrm{Nd}_{i}=-4.4$ to -10.7 ) (Beetsma, 1995) and the potential crustal source reservoirs shown in Fig. 12. Although these granites may have been generated by partial melting of entirely metasedimentary protoliths with less evolved isotopic signatures (not exposed), which will be consis- 
tent with their S-type affinities, their initial isotopic compositions are equally well explained in terms of $\mathrm{AFC}$ processes. If so, a genetic relationship with the other intrusive members of the FAC may be implied.

The scarcity of mafic and intermediate rocks with positive $\varepsilon \mathrm{Nd}_{i}$ and low $\varepsilon \mathrm{Sr}_{i}$ values and compositions more basic than granodiorite appears to distinguish the Hercynian granitoids from those of other regions where a depleted-mantle contribution has been clearly established (e.g., South American Cordillera (Pankhurst et al., 1988), North American Cordillera (DePaolo, 1981; DePaolo and Farmer, 1984; Silver and Chappell, 1988). This has led a number of authors to rule out a direct involvement of mantle-derived magmas in the genesis of the Hercynian granites (e.g., Michard-Vitrac et al., 1980; Turpin et al., 1990). However, the formation of sizeable bodies of highly viscous granitic melts is thought to offer a density and thermal barrier to the upwelling of mafic liquids (Pitcher, 1993). As such, the limited occurrence of basic and intermediate igneous rocks does not constitute sufficient evidence for excluding the intervention of mantle extracts in the production of granite magmas.

On the basis of the isotopic data presently available, the nature of the processes and source materials involved in the petrogenesis of the 'main suite' FAC granitoids cannot be unambiguously constrained. Nevertheless, the isotopic results are clearly incompatible with a model of closed-system ageing and differentiation of a common parental magma suggesting, instead, an important role for magma mixing and AFC type processes.

\section{Conclusions}

A 'mixed' source origin for the main suite FAC parental magmas is strongly supported by the isotopic heterogeneity observed both within and between the GD, CPBG, CGTG and MGTG intrusions. The low- $\varepsilon \mathrm{Sr}$, high- $\varepsilon \mathrm{Nd}$ values $\left(\varepsilon \mathrm{Sr}_{i}=13.35-14.75\right.$; $\left.\varepsilon \mathrm{Nd}_{i}=0.01\right)$ displayed by the more primitive members of the sequence is not inconsistent with a direct input of mantle-derived material. This is corroborated by their I-type affinities and the widespread occurrence of mafic microgranular enclaves within the CPBG. Basic magmas with chemical and isotopic composition similar to the Viseu gabbros may have provided the low $\mathrm{Sr}$-high $\mathrm{Nd}$ mixing end-member whereas a metasedimentary protolith comparable to the Late Proterozoic/Cambrian complex (CXG) constitutes a potential candidate for the felsic component (Fig. 12).

It is therefore possible to envisage a scenario where the intrusion of mantle-derived magmas into an already thickened Variscan continental crust $(\approx 40$ $\mathrm{km}$ ) induces dehydration melting of lower crustal metasedimentary protoliths with compositions similar to the CXG and consequent production of substantial amounts of felsic melts. Extensive interaction between crustal and mantle-derived melts through mixing together with fractional crystallization could have produced large bodies of hybrid CPBG magmas at depth.

In this model, the genesis of the hornblende granodiorites and the mafic microgranular enclaves is reasonably well explained in terms of direct fractionation of a basaltic precursor or, more probably, concurrent fractional crystallization and hybridization of such magmas with only small amounts of felsic melts. The injection of successive pulses of the basic component into upward mobile CPBG magma chambers would have resulted in the formation of the MME. This could account for both the compositional diversity shown by the MME and the complex field, mineralogical and textural relationships observed between the MME and their host granitoids.

During the subsequent ascent of the CPBG magma bodies into progressively higher crustal levels, fractional crystallization and further contamination with metasedimentary material (AFC) may have dominated the evolutionary path of the CPBG producing a series of more differentiated batches of slightly peraluminous two-mica granitoid melts (CPTG, MPTG, CGTG, MGTG). Finally, the segregation of extremely fractionated felsic liquids at a very late stage in the evolution of the granite sequence is probably responsible for the formation of dikes and minor plutons of muscovite-tourmaline-garnet-bearing granites (MG).

\section{Acknowledgements}

We would like to thank Matthew Thirlwall for the use of the isotopic facilities at Royal Holloway and 
Bedford New College (RHBNC) and assistance with the isotopic analysis, Peter Watkins for assistance with the ICP-AES analysis at Imperial College, Oscar Carvalho for assistance in the field, Luis Pinheiro, Val Hervalejo and Estela Martins for computing assistance, José Francisco Santos and Beatriz Valle for helpful discussions. We are further grateful to Colombo Tassinari, Liliane Petronilho and Kei Sato for assistance with additional isotopic analyses at the University of São Paulo (Brazil). Thorough reviews and valuable comments by M.P Atherton and W.E. Stephens are greatly appreciated.

\section{References}

Allègre, C.J., Ben Othman, D., 1980. Nd-Sr isotopic relationship in granitoid rocks and continental crust development: A chemical approach to orogenesis. Nature 286, 335-342.

Atherton, M.P., Sanderson, L.M., 1987. The Cordillera Blanca batholith: A study of granite intrusion and the relation of crustal thickening to peraluminosity. Geologische Rundschau 76, 213-232.

Azevedo, M.R., 1996. Hercynian granitoids from the Fornos de Algodres Area (Northern Central Portugal). PhD Thesis, Imperial College, London, 440 pp., unpublished.

Banda, E., Udias, A., Mueller, S., Mezcua, J., Boloix, M., Gallart, J., Aparico, A., 1983. Crustal structure beneath Spain from deep seismic sounding experiments. Physics of the Earth and Planet. Int. 31, 277-280.

Barbarin, B., Didier, J., 1991. Review of the main hypotheses proposed for the genesis and evolution of mafic microgranular enclaves. In: Didier, J., Barbarin, B. (Eds.), Enclaves and Granite Petrology. Developments in Petrology, 13, Elsevier, London, pp. 367-373.

Beetsma, J.J., 1995. The late Proterozoic/Paleozoic and Hercynian crustal evolution of the Iberian Massif, N Portugal. PhD Thesis, Vrije University, Netherlands, 223 pp., unpublished.

Bergantz, G.W., 1989. Underplating and partial melting: Implications for melt generation and extraction. Science 245, 1093 1095.

Bernard-Griffiths, J., Peucat, J.J., Sheppard, S., Vidal, Ph., 1985. Petrogenesis of Hercynian leucogranites from the southern Armorican Massif: contribution of REE and isotopic ( $\mathrm{Sr}, \mathrm{Nd}$, $\mathrm{Pb}$ and $\mathrm{O})$ geochemical data to the study of source rock characteristics and ages. Earth and Planet. Sci. Lett. 74, 235250.

Brown, G.C., Thorpe, R.S., Webb, P.C., 1984. The geochemical characteristics of granitoids in contrasting arcs and comments on magma sources. J. Geol. Soc. London 141, 413-442.

Bussy, F., 1991. Enclaves of the Late Miocene Monte Capanne granite, Elba Island, Italy. In: Didier, J., Barbarin, B. (Eds.), Enclaves and Granite Petrology. Developments in Petrology, 13, Elsevier, London, pp. 167-178.
Capdevila, R., Corretgé, L.G., Floor, P., 1973. Les granitöides varisques de la Meseta Ibérique. Bull. Soc. Géol. France 15, 209-228.

Chappell, B.W., 1984. Source rocks of I- and S-type granites in the Lachlan Fold Belt, southeastern Australia. Phil. Trans. R. Soc. London A 310, 693-707.

Chappell, B.W., Stephens, W.E., 1988. Origin of infracrustal (I-type) granite magmas. Trans. R. Soc. Edinburgh Earth Sci. 79, 71-86.

Chappell, B.W., White, A.J.R., 1974. Two contrasting granite types. Pac. Geol. 8, 173-174.

Córdoba, D., Banda, E., Ansorge, J., 1987. The Hercynian crust in Northwestern Spain: A review. Tectonophysics 132, 321-333.

Czamanske, G.K., Ishihara, S., Atkin, S.A., 1981. Chemistry of rock-forming minerals of the Cretaceous Paleocene batholith in southwestern Japan and implications for magma genesis. J. Geophys. Res. 86 (B11), 10431-10469.

DePaolo, D.J., 1981. A Nd and Sr Isotopic study of the Mesozoic calc-alkaline granitic batholiths of the Sierra Nevada and Peninsula Ranges, California. J. Geophys. Res. 86, 1047010488.

DePaolo, D.J., Farmer, G.L., 1984. Isotope data bearing on the origin of Mesozoic and Tertiary granitic rocks in the western United States. Phil. Trans. R. Soc. London A 310, 753-753.

DePaolo, D.J., Wasserburg, G.J., 1979. Petrogenetic mixing models and $\mathrm{Nd}-\mathrm{Sr}$ isotopic patterns. Geochim. Cosmochim. Acta 43, 615-627.

Dewey, J.F., Shackleton, R.M., Chang, C., Sun, Y., 1988. The tectonic evolution of the Tibetan Plateau. Phil. Trans. R. Soc. London A 327, 379-413.

Dias, G., Leterrier, J., 1994. The genesis of mafic-felsic plutonic associations: A $\mathrm{Sr}$ and $\mathrm{Nd}$ isotopic study of the Hercynian Braga granitoid massif (Northern Portugal). Lithos 32, $207-$ 223.

Diez Balda, M.A., Vegas, R., Gonzalez Lodeiro, F., 1990. Central Iberian Zone: structure. In: Dallmeyer, R.D., Martinez Garcia, E. (Eds.), Pre-Mesozoic Geology of the Iberian Peninsula. Springer, Berlin, pp. 172-188.

England, P.C., Houseman, G.A., 1988. The mechanics of the Tibetan Plateau. Phil. Trans. R. Soc. London A 326, 301-319.

Evensen, N.H., Hamilton, P.J., O’Nions, R.K., 1978. Rare earth abundances in chondrite meteorites. Geochim. Cosmochim. Acta 42, 1199-1212.

Faure, G., 1986. Principles of Isotope Geology, 2nd edn., Wiley, New York, $589 \mathrm{pp}$

Ferreira, N., Iglesias Ponce de Léon, M., Noronha, F., Ribeiro, A., Ribeiro, M.L., 1987. Granitóides da Zona Centro Ibérica e seu enquadramento geodinâmico. In: Bea, F., Carnicero, A., Gonzalo, J.C., López Plaza, M., Rodriguez Alonso, M.D. (Eds.), Geologia de los Granitoides e Rocas asociadas del Macizo Hespérico. Editorial Rueda, Madrid, pp. 37-51.

Frost, T.P., Mahood, G.A., 1987. Field, physical and chemical constraints on mafic-felsic magma interaction in the Lamarck granodiorite, Sierra Nevada, California. Geol. Soc. Am. Bull. 99, 272-291.

Gasquet, D., Leterrier, J., Mrini, Z., Vidal, Ph., 1992. Petrogenesis of the Hercynian Tichka plutonic complex (Western High 
Atlas, Morocco): Trace element and $\mathrm{Rb}-\mathrm{Sr}$ and $\mathrm{Sm}-\mathrm{Nd}$ isotopic constraints. Earth and Planet. Sci. Lett. 108, 29-44.

Halliday, A.N., Stephens, W.E., Harmon, R.S., 1981. Isotopic and chemical constraints on the development of peraluminous Caledonian and Acadian granites. Can. Mineral. 19, 205-216.

Hammarstrom, J.M., Zen, E-An., 1986. Aluminium in hornblende: An empirical igneous geobarometer. Am. Mineral. 71, 12971313.

Holdaway, M.J., 1971. Stability of andalusite and the aluminum silicate phase diagram. Am. J. Sci. 271, 97-131.

Iglesias, M., Ribeiro, A., 1981. La zone de cisaillement ductile de Juzbado (Salamanca)-Penalva do Castelo (Viseu): Un linéament ancien reactivé pendant l'orogenese Hercynienne? Comun. Serv. Geol. Portugal 67 (1), 89-93.

Johnson, M.C., Rutherford, M.J., 1989. Experimental calibration of the aluminum-in-hornblende geobarometer with application to Long Valley caldera (California) volcanic rocks. Geology 17, 837-841.

Langmuir, C.H., Vocke, R.D., Hanson, G.N., Hart, S.R., 1978. A general mixing equation with application to Icelandic basalts. Earth and Planet. Sci. Lett. 37, 380-392.

Liew, T.C., McCulloch, M.T., 1985. Genesis of granitoid batholiths of Peninsular Malaysia and implications for crustal evolution: Evidence from a $\mathrm{Nd}-\mathrm{Sr}$ and $\mathrm{Pb}-\mathrm{U}$ zircon study. Geochim. Cosmochim. Acta 49, 587-600.

Luth, W.C., Jahns, R.H., Tuttle, O.F., 1964. The granite system at pressures of 4 to 10 kilobars. J. Geophys. Res. 69, 759-773.

Matias, L.M.H.M., 1996. A sismologia experimental na modelação da estrutura da crusta em Portugal Continental. PhD Thesis, University of Lisbon, Lisbon, 398 pp., unpublished.

Matte, P., 1986. Tectonics and plate tectonic model for the Variscan Belt of Europe. Tectonophysics 126, 329-374.

McCulloch, M.T., Chappell, B.W., 1982. Nd isotope characteristics of S- and I-type granites. Earth and Planet. Sci. Lett. 58, 51-64.

Michard-Vitrac, A., Albaréde, F., Dupuis, C., Taylor, H.P. Jr., 1980. The genesis of Variscan (Hercynian) plutonic rocks: Inferences from $\mathrm{Sr}, \mathrm{Pb}$ and $\mathrm{O}$ studies on the Maladeta igneous complex, Central Pyrenees (Spain). Contrib. Mineral. Petrol. $72,57-72$.

Nachit, H., Razafimahefa, N., Stussi, J.M., Carron, J.P., 1985. Composition chimique des biotites et typologie magmatique des granitoïdes. C.R. Acad. Sci. Paris 301 (11), 813-818.

Noronha, F., Ramos, J.M.F., Rebelo, J.A., Ribeiro, A., Ribeiro, M.L., 1981. Essai de corrélation des phases de déformation hercyniennes dans le nord-ouest Péninsulaire. Leidse Geol. Mededel 52, 87-91.

O’Nions, R.K., Evensen, N.M., Hamilton, P.J., 1979. Geochemical modeling of differentiation and crustal growth. J. Geophys. Res. 84, 6091-6101.

Orsini, J.B., Cocirta, C., Zorpi, M.J., 1991. Genesis of mafic microgranular enclaves through differentiation of basic magmas, mingling and chemical exchanges with their host granitoid magmas. In: Didier, J., Barbarin, B. (Eds.), Enclaves and Granite Petrology. Developments in Petrology, 13, Elsevier, London, pp. 445-463.

Ortega, L.A., Gil Ibarguchi, J.I., 1989. The genesis of late Hercy- nian granitoids from Galicia (Northwestern Spain): Inferences from REE studies. J. Geol. 98, 189-211.

Pankhurst, R.J., Hole, M.J., Brook, M., 1988. Isotope evidence for the origin of the Andean granites. Trans. R. Soc. Edinburgh Earth Sci. 79, 123-133.

Peucat, J.J., Bernard-Griffiths, J., Gil Ibarguchi, J.I., Dallmeyer, R.D., Menot, R.P., Cornichet, J., Iglesias Ponce de Léon, M., 1990. Geochemical and geochronological cross-section of the deep Variscan crust: The Cabo Ortegal high pressure nappe (NW Spain). Tectonophysics 177, 263-292.

Pickett, D.A., Wasserburg, G.J., 1989. Neodymium and strontium isotopic characteristics of New Zealand granitoids and related rocks. Contrib. Mineral. Petrol. 103, 131-142.

Pin, C., Duthou, J.L., 1990. Sources of Hercynian granitoids from the French Massif Central: Implications from Nd isotopes and consequences for crustal evolution. Chem. Geol. 83, 281-296.

Pinto, M.S., Casquet, C., Ibarrola, E., Corretgé, L.G., Portugal Ferreira, M., 1987. Síntese geocronológica dos granitóides do Maciço Hespérico. In: Bea, F., Carnicero, A., Gonzalo, J.C., López Plaza, M., Rodriguez Alonso, M.D. (Eds.), Geologia de los Granitoides e Rocas Asociadas del Macizo Hespérico. Editorial Rueda, Madrid, pp. 69-86.

Pitcher, W.S., 1993. The Nature and Origin of Granite. Chapman and Hall, London, $321 \mathrm{pp}$.

Quesada, C., 1991. Geological constraints on the Palaeozoic tectonic evolution of tectonostratigraphic terranes in the Iberian Massif. Tectonophysics 185, 225-245.

Reid, J.B., Evans, O.C., Fates, D.G., 1983. Magma mixing in granitic rocks of the central Sierra Nevada, California. Earth and Planet. Sci. Lett. 66, 243-261.

Ribeiro, A., Iglesias, M., Ribeiro, M.L., Pereira, E., 1983. Modèle geodynamique des Hercynides Ibériques. Com. Serv. Geol. Portugal LXIX, 291-294.

Ribeiro, A., Quesada, C., Dallmeyer, R.D., 1990. Geodynamic evolution of the Iberian Massif. In: Dallmeyer, R.D., Martinez Garcia, E. (Eds.), Pre-Mesozoic Geology of the Iberian Peninsula. Springer, Berlin, pp. 399-409.

Shaw, A., 1991. The petrogenesis of Hercynian granites, French Massif Central. PhD Thesis, University of London, UK, 285 pp., unpublished.

Schmidt, M.W., 1992. Amphibole composition in tonalite as a function of pressure: an experimental calibration of the Al-inhornblende barometer. Contrib. Mineral. Petrol. 110, 304-310.

Silver, L.T., Chappell, B.W., 1988. The Peninsular Ranges Batholith: An insight into the evolution of the Cordilleran batholiths of southwestern North America. Trans. R. Soc. Edinburgh Earth Sci. 79, 105-121.

Tassinari, C.C.G., Medina, J., Pinto, M.S., 1995. Combined Rb-Sr and $\mathrm{Sm}-\mathrm{Nd}$ geochronology and isotope geochemistry of Central Iberian metasedimentary rocks (Portugal). in press.

Thirlwall, M.F., 1991. Long-term reproducibility of multicollector $\mathrm{Sr}$ and $\mathrm{Nd}$ isotope ratio analysis. Chem. Geol. 94, 85-104.

Turpin, L., Cuney, M., Friedrich, M., Bouchez, J.L., Aubertin, M., 1990. Meta-igneous origin of Hercynian peraluminous granites in NW French Massif Central: Implications for crustal history reconstructions. Contrib. Mineral. Petrol. 104, 163-172.

Valle, B.A., 1992. Geología estructural de la Zona de Cisalla de 
Porto-Tomar en la región de Oliveira de Azeméis-Serra de Arada (Norte de Portugal). PhD Thesis, University of Salamanca, España, 254 pp., unpublished.

Valle, B.A., Arenas, R., Martínez Catalán, J.R., 1993. Evolución metamórfica hercínica en la región de la Serra de Arada (Norte de Portugal). Comun. Inst. Geol. Mineiro de Portugal 79, 41-61.

Vernon, R.H., 1983. Restite, xenoliths and microgranitoid enclaves in granites. J. Proc. R. Soc. N.S.W. 116, 77-103.

Vernon, R.H., 1984. Microgranitoid enclaves in granites-globules of hybrid magma quenched in the plutonic environment. Nature 309, 438-439.

Vernon, R.H., 1990. Crystallization and hybridism in microgranitoid enclave magmas: Microstructural evidence. J. Geophys. Res. 95, 17849-17859.

Wall, V.J., Clemens, J.D., Clarke, D.B., 1987. Models for granitoid evolution and source compositions. J. Geol. 95, 731-749.

Watkins, P.J., Nolan, J., 1990. Determination of rare-earth elements, scandium yttrium and hafnium in 32 geochemical reference materials using inductively coupled plasma-atomic emission spectrometry. Geostandards Newsletter 14 (1), 11-20.

Watkins, P.J., Nolan, J., 1992. Determination of rare-earth elements, yttrium, scandium and hafnium using cation-exchange separation and inductively coupled plasma-atomic emission spectrometry. Chem. Geol. 95, 131-139.
White, A.J.R., 1990. Unpublished notes accompanying 'A workshop on crustal protoliths of granites'. University of St. Andrews, 12th January, 1990.

White, A.J.R., Chappell, B.W., 1988. Some supracrustal (S-type) granites of the Lachlan Fold Belt. Trans. R. Soc. Edinburgh Earth Sci. 79, 169-181.

White, A.J.R., Clemens, J.D., Holloway, J.R., Silver, L.T., Chappell, B.W., Wall, V.J., 1986. S-type granites and their possible absence in southwestern North America. Geology 14, 115-118.

Wiebe, R.A., 1991. Commingling of magmas and generation of mafic enclaves in granitic rocks. In: Didier, J., Barbarin, B. (Eds.), Enclaves and Granite Petrology. Developments in Petrology, 13, Elsevier, London, pp. 393-402.

Winkler, H.G.F., 1976. Petrogenesis of Metamorphic Rocks. Springer, New York, 237 pp.

Wyborn, D., Chappell, B.W., 1986. The petrogenetic significance of chemically related plutonic and volcanic rock units. Geol. Magazine 123, 619-628.

Yardley, B.W.D., 1989. An Introduction to Metamorphic Petrology. Longman Group UK, Essex. 248 pp.

York, D., 1969. Least squares fitting of a straight line with correlated errors. Earth and Planet. Sci. Lett. 5, 320-324. 